\title{
On the Reactivity of Naphthalene and Biphenyl Dianions: Tying up Loose Ends concerning an SN2-ET Dichotomy in Alkylation Reactions
}

\begin{tabular}{|r|l|}
\hline Journal: & Journal of Physical Organic Chemistry \\
\hline Manuscript ID: & POC-14-0121 \\
\hline Wiley - Manuscript type: & Research Article \\
\hline Date Submitted by the Author: & 25 -Jun-2014 \\
\hline Complete List of Authors: & $\begin{array}{l}\text { Guijarro, Albert; Universidad de Alicante, Departamento de Química } \\
\text { Orgánica and Instituto de Síntesis Orgánica } \\
\text { Blasco, Inmaculada; Universidad de Alicante, Departamento de Química } \\
\text { Orgánica and Instituto de Síntesis Orgánica } \\
\text { Perez, Henoc; Universidad de Alicante, Departamento de Química Orgánica } \\
\text { and Instituto de Síntesis Orgánica }\end{array}$ \\
\hline Keywords: & $\begin{array}{l}\text { SN2/ET dichotomy, naphthalene dianion, biphenyl dianion, } \\
\text { cyclopropylmethyl fluoride, very fast radical probe }\end{array}$ \\
\hline
\end{tabular}




\title{
On the Reactivity of Naphthalene and Biphenyl Dianions: Tying up Loose Ends concerning an $\mathrm{S}_{\mathrm{N}} 2$-ET Dichotomy in Alkylation Reactions
}

\author{
Inmaculada Blasco ${ }^{a}$, Henoc Pérez ${ }^{a}$, and Albert Guijarro ${ }^{a}$ *
}

Double reduction of naphthalene as well as biphenyl to the dianion stage can be achieved with lithium in solution under certain conditions. These dianions are highly reactive and rather elusive species that share many aspects of the reactivity of the alkali metal they originated from, and in consequence, behave primarily as strong electron transfer (ET) reagents. We report in here kinetic evidence of a different type of reactivity in their reactions of alkylation with alkyl fluorides. By using cyclopropylmethyl fluoride $\left(c-\mathrm{C}_{3} \mathrm{H}_{5} \mathrm{CH}_{2} \mathrm{~F}\right)$ as a very fast radical probe, we were able to discern this mechanistic $\mathrm{S}_{\mathrm{N}}$ 2-ET dichotomy, and settle that this alkylation does not involve the classical electron transfer reaction followed by radical coupling between diffusing radicals, but supports the alternative $\mathrm{S}_{\mathrm{N}} 2$ concerted mechanism.

Supporting information may be found in the online version of this paper

Keywords: $\mathrm{S}_{\mathrm{N}} 2 / \mathrm{ET}$ dichotomy; very fast radical probe; naphthalene dianion; biphenyl dianion; cyclopropylmethyl fluoride.

* Correspondence to: Albert Guijarro, Departamento de Química Orgánica and Instituto de Síntesis Orgánica. Universidad de Alicante. Campus de Sant Vicent del Raspeig, Apdo. 99, E-03080, Alicante, Spain

E-mail: aguijarro@ua.es

${ }^{a}$ Inmaculada Blasco, Henoc Pérez, Albert Guijarro

Departamento de Química Orgánica and Instituto de Síntesis Orgánica. Universidad de Alicante. Campus de Sant Vicent del Raspeig, Apdo. 99, E-03080, Alicante, Spain

\section{INTRODUCTION}

Under certain conditions, lithium naphthalene $\left(\mathrm{LiC}_{10} \mathrm{H}_{8}, \mathrm{LiNp}\right)$ as well as lithium biphenyl $\left(\mathrm{LiC}_{12} \mathrm{H}_{10}, \mathrm{LiBp}\right)$ can be over-reduced with $\mathrm{Li}_{(\mathrm{s})}$ to afford even more reduced species, i.e., the corresponding dianions $\mathrm{Li}_{2} \mathrm{C}_{10} \mathrm{H}_{8}\left(\mathrm{Li}_{2} \mathrm{~Np}\right)$ and $\mathrm{Li}_{2} \mathrm{C}_{12} \mathrm{H}_{10}\left(\mathrm{Li}_{2} \mathrm{Bp}\right)$, respectively. ${ }^{1,2}$ There are many fundamental aspects that remain to be explored in these compounds, so we got involved some time ago in the study of the structure and reactivity of these species. The structure of lithium naphthalene dianion $\mathrm{Li}_{2} \mathrm{C}_{10} \mathrm{H}_{8}$ obtained in this way was elucidated only recently, revealing an ionic contact triple (triple meaning three ions) in the ground state. $^{3}$ In the case of biphenyl, the experimental crystal structure is yet unknown, but $a b$ initio and DFT calculations foresee a similar type of structure and bonding, i.e., an ionic contact triple in the ground state (Figure 1). ${ }^{4}$ In spite of a profound change in the electron configuration of the hydrocarbon during its reduction, going from an open-shell radical anion, to a closed-shell configuration in the dianion, these changes occur while preserving the structural identity of the arene. This provides an opportunity to study the reactivity of these species from a unique perspective. Both in the radical anion and dianion, the vacant $\pi$-LUMO of the parent hydrocarbon has been occupied by one or two extra electrons coming from the lithium metal. The resulting anions have both very high-lying and highly delocalized electrons. This dictates much of their reactivity, which is often reminiscent of the alkali metal they originated from. Still, over-reduction to the dianion is not a trivial issue for these small arenes. The second reduction potentials $\left(E_{2}^{\mathrm{o}}\right)$ of naphthalene and biphenyl rival with the $\mathrm{Li}_{(\mathrm{s})} / \mathrm{Li}^{+}$pair, ${ }^{5}$ leaving only a narrow window for a feasible (exergonic) double reduction of these hydrocarbons. ${ }^{6}$ Indeed, the double reduction of naphthalene with $\operatorname{Li}_{(\mathrm{s})}$ in THF is expected to be unfeasible $\left(\Delta G^{\mathrm{o}}>0\right)$ if formulated solely on electrochemical grounds, which does not takes into account the lithium ion pairing stabilization, and it is also so for biphenyl under the same premises. ${ }^{7}$ As a result, these compounds are powerful electron transfer (ET) reagents. In spite of that, new patterns of reactivity (other than ET) that are ascribed solely to the dianion (and not to the radical anion) were recently identified. Lithium dianions of naphthalene and biphenyl have displayed unexpected nucleophilic 
behavior versus simple alkenes, affording carbolithiation products with propene, isobutene, etc. ${ }^{8}$ Also, in its reaction with $n$-, $s$ and $t$-alkyl fluorides, competitive kinetics revealed for dilithium naphthalene a reactivity profile consistent with a $\mathrm{S}_{\mathrm{N}}$ (nucleophilic substitution) reaction pathway. ${ }^{9}$ Alkylated dihydronaphthalenes were apparently obtained in these reactions through a mechanism $\left(\mathrm{S}_{\mathrm{N}}\right)$ different from the classical mechanistic view that involves ET and coupling between difussing radicals; ${ }^{10}$ a classical mechanism valid otherwise for the rest of alkyl halides ( $\mathrm{RCl}, \mathrm{RBr}$ and $\mathrm{RI})$. In this work, we use cyclopropylmethyl fluoride (1a) as a fast radical probe to shed light on this $\mathrm{S}_{\mathrm{N}} / \mathrm{ET}$ mechanistic dichotomy, and also raise the attention to the fact that this issue was not settled beyond doubt in the past by using slower radical probes such as 5-hexenyl fluoride (1b).

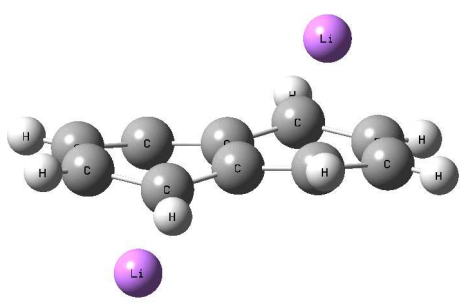

$\mathrm{Li}_{2} \mathrm{Naphthalene}$

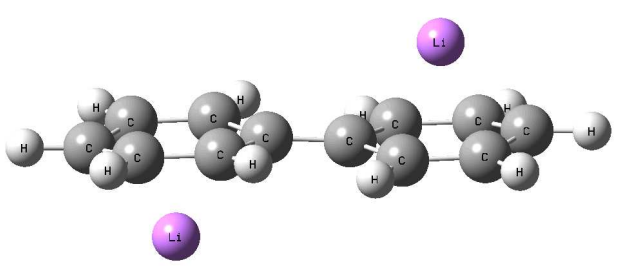

$\mathrm{Li}_{2}$ Biphenyl

Figure 1. Dilithium naphthalene $\left(\mathrm{Li}_{2} \mathrm{~Np}\right)$ from $\mathrm{X}$-Ray crystallography (coordinating TMEDA omitted for simplicity) $;^{3}$ and dilithium biphenyl $\left(\mathrm{Li}_{2} \mathrm{Bp}\right)$ from DFT calculations. ${ }^{4 \mathrm{~b}}$

\section{RESULTS AND DISCUSSION}

\section{Cyclopropylmethyl Fluoride as a Very Fast Radical Probe}

The synthesis of cyclopropylmethyl fluoride (1a) with an adequate level of purity, in particular, free from rearranged isomers, was necessary for our purposes. It proved to be not an easy task. Cyclopropylmethyl fluoride is a reagent conspicuously missing from the chemical literature, except for a few instances. In general, an adequate description of its synthesis and isolation is lacking while many details are omitted, as noticed by Percy. ${ }^{11} \mathrm{We}$ started an extensive search for synthetic methodologies to obtain pure cyclopropylmethyl fluoride. In general, nucleophilic fluorination of cyclopropylmethanol derivatives proved to be the method of choice, while other approaches such as cyclopropanation of allyl fluoride $\left(\mathrm{CH}_{2}=\mathrm{CHCH}_{2} \mathrm{~F}\right)$ failed to give de desired compound, affording only homoallyl fluoride $\left(\mathrm{CH}_{2}=\mathrm{CHCH}_{2} \mathrm{CH}_{2} \mathrm{~F}\right)$. There are two main synthetic procedures described in the literature. First, the synthesis of 1a was described by reaction of cyclopropylmethanol with DAST $\left(\mathrm{Et}_{2} \mathrm{NSF}_{3}\right)$ in diglyme at $-50^{\circ} \mathrm{C}$ and low temperature-low pressure fractionation column. ${ }^{12}$ There is no evidence of the purity of the distilled fraction, nor yields. In our hands, the reaction product always turned out to be an inseparable mixture of two isomers of cationic rearrangement (cyclobutyl fluoride as mayor component and cyclopropylmethyl fluoride in a 1.6:1 ratio). Our attempts to improve these results modifying the reaction conditions ( $T$, solvent) and equipment, as well as using alternative fluorinating reagents such as Yarovenko's and Ishikawa's reagents, were unsuccessful. A second published approach, ${ }^{13}$ involves the nucleophilic substitution of cyclopropylmethyl tosylate (2a), ${ }^{14}$ with $\mathrm{TBAF} \cdot 3 \mathrm{H}_{2} \mathrm{O}$ $\left(\mathrm{Bu}_{4} \mathrm{~N}^{+} \mathrm{F}^{-} \cdot 3 \mathrm{H}_{2} \mathrm{O}\right)$, which had been previously partially-dehydrated by a thermal treatment under vacuum. ${ }^{15}$ According to the authors, the volatiles of the reaction were then vacuum transferred into an empty ampule, giving two layers, an aqueous and an organic one, this last one consisting of $\sim 50 \%$ of cyclopropylmethyl fluoride along with olefins and other unidentified products. ${ }^{13}$ Then that crude 
organic mixture was further purified (to $>95 \%$ ) by treating it with $\mathrm{Cp}^{*}{ }_{2} \mathrm{ZrH}_{2}$, but no spectroscopic evidence of purity was either reported. ${ }^{16}$ Finally, a reference to this paper has been published, although there is no description of the actual synthesis and purification of 1a. ${ }^{17}$ The synthesis of cyclopropylmethyl fluoride by nucleophilic fluorination of an appropriate cyclopropylmethyl derivative initially confronted us with an additional problem: the easy cationic isomerisation of this structure. It occurs via the cyclopropylmethyl carbocation triad, which includes the cyclobutyl and 3butenyl cations. Details of this cationic rearrangement can be found in the supplementary information (Scheme S1 and S2). After a scrutiny of several alternatives, cyclopropylmethyl tosylate (2a) was chosen as the starting material to obtain 1a. 2a Has been described as a liquid too unstable to purify by distillation. ${ }^{18}$ It has been obtained in variable yields (when reported) ranging from $66 \%,{ }^{19}$ $85-93 \%,{ }^{20} 68.5 \%{ }^{21}$ It is often overlooked in the synthetic literature that $\mathbf{2 a}$ is a rather unstable compound that should be carefully manipulated to avoid the above mentioned skeletal rearrangements as well as further decomposition. To prevent this isomerization, we have successfully optimized the synthesis of $2 \mathbf{a}$ using low temperature, and solvents of low ionizing power $\left(\varepsilon_{\mathrm{r}}<10\right)$ during the synthetic process. Obtained in this way, 2a is a low melting point white solid $\left(\mathrm{mp}=16-17^{\circ} \mathrm{C}\right.$, uncorrected). As a nucleophilic fluoride source, tetrabutylammonium fluoride (TBAF) turned out to be the most indicated for avoiding unwanted structural rearrangements. Thus, reaction with TBAF ( $1 \mathrm{M}$ in THF) at $5^{\circ} \mathrm{C}$, and collection of the volatiles in a cold trap afforded a $c a$. $25 \%$ of cyclopropylmethyl fluoride (1a), which could be easily purify to $>95 \%$ pure product, suitable for our purposes (Scheme 1 and experimental).
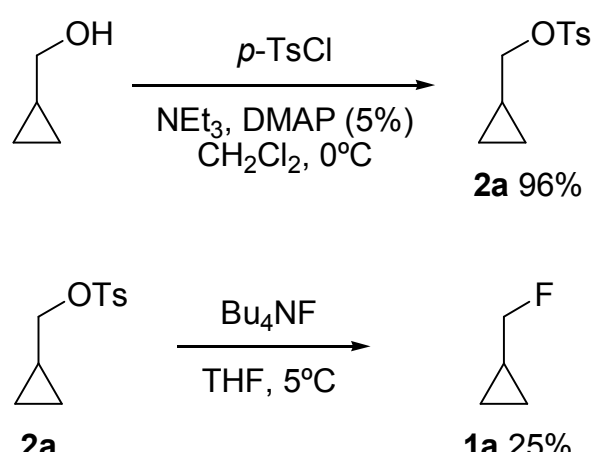

1a $25 \%$

Scheme 1.

\section{Antecedents with Other Radical Probes}

In previous studies we studied the reaction of $\mathrm{LiBp}$ and $\mathrm{Li}_{2} \mathrm{Bp}$ with a radical probe (hex-5enyl fluoride, 1b) in $\mathrm{THF}$ and $\mathrm{THP}$ at $0^{\circ} \mathrm{C}$, paying special attention to the distribution of products observed. ${ }^{2}$ It was significant that, among the alkylated products $(>80 \%$ overal yield for $\mathrm{Li}_{2} \mathrm{Bp}$ ), no rearranged products was observed (see Schemes 2, 3 and the structures of R' and rearranged R' below). The concentration of $\mathbf{4} \mathbf{b}^{\prime}$ remained zero (i.e., undetectable by GLC, contrasted using an authentic synthesized sample of $\mathbf{4 b}^{\text {') }}$ in experiments of dilution $\left(\left[\mathrm{Li}_{2} \mathrm{Bp}\right]=0.1,0.05\right.$ and $0.01 \mathrm{M})$. The same conclusions were reached for the naphthalene dianion $\mathrm{Li}_{2} \mathrm{~Np}$. In its reaction with the same radical probe (1b) in THP at $0^{\circ} \mathrm{C}, \mathrm{Li}_{2} \mathrm{~Np}$ afforded a $76 \%$ overall yield of alkylation products, from which $0 \%$ were rearranged (also confirmed by GLC after synthesis of the rearranged products), and remained so in experiments of dilution $\left(\left[\mathrm{Li}_{2} \mathrm{~Np}\right]=0.1,0.05\right.$, and $\left.0.01 \mathrm{M}\right)$. Preparation of solutions below $10^{-2} \mathrm{M}$ was not considered reliable enough by the method of direct reduction with $\mathrm{Li}_{(\mathrm{s})}$ (lithium powder obtained by milling of a lithium bar), so no further experiments at higher dilution were considered. These facts led us to think that the alkylation reaction of $\mathrm{Li}_{2} \mathrm{Bp}$ or $\mathrm{Li}_{2} \mathrm{~Np}$ with primary fluororalkanes was likely to proceed through an $\mathrm{S}_{\mathrm{N}} 2$ transition state, although being igurous the potential role of radicals in the reaction could not be discarded. 

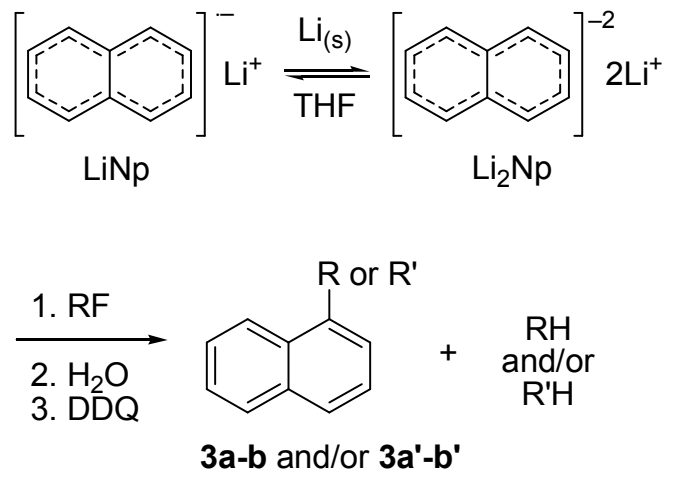

Scheme 2. Reaction of $\mathrm{Li}_{2} \mathrm{~Np}$ with $\mathrm{RF}(\mathrm{R}=$ radical probe, see structure of $\mathrm{R}$ below)

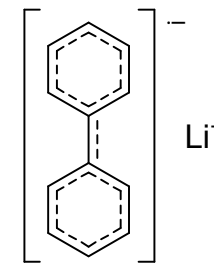

LiBp

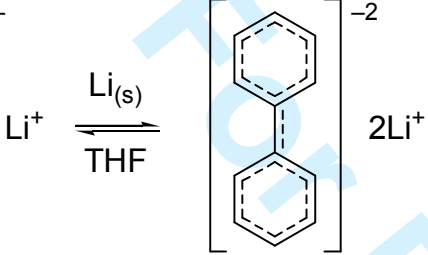

$\mathrm{Li}_{2} \mathrm{Bp}$
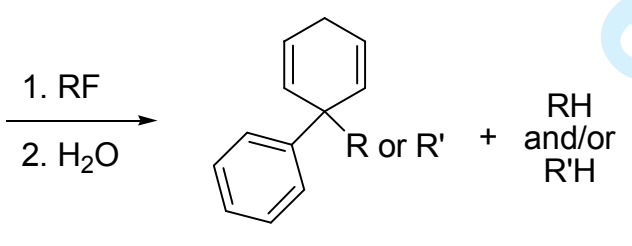

$4 a-b$ and/or $4 a^{\prime}-b^{\prime}$

Scheme 3. Reaction of $\mathrm{Li}_{2} \mathrm{Bp}$ with $\mathrm{RF}(\mathrm{R}=$ radical probe, see structure of $\mathrm{R}$ below)

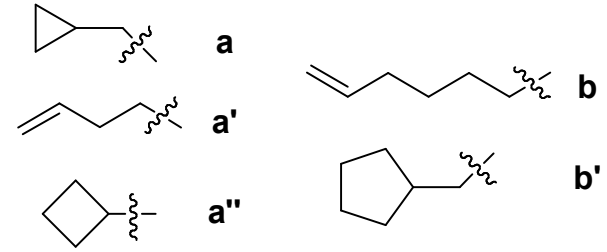

Structure of R (unrrearranged) and R', R', (rearranged).

Let us evaluate now quantitatively the reason for this last statement.

\section{The Kinetic Scheme of the Reaction}

The complete set of reactions has been represented in Scheme 4. We shall consider first the hypothetical scenario in which alkylation of the arene takes place only by radical coupling, and not by nucleophilic substitution (i.e., we set $k_{\mathrm{SN}}=0$ ). Should this scenario be impossible, the alternative scenario, i.e. alkylation of the arene taking place by nucleophilic substitution, must be true (reductio ad absurdum), since alternative mechanisms of alkylation seem unlikely. From the rate laws derived from Scheme 4 (equations 1 and 2), equation 3 is obtained. Applying the steady state approximation (SSA) to a short lived intermediate (equation $4)$, the ratio between radicals $[\mathrm{R} \cdot] /\left[\mathrm{R}^{\prime} \cdot\right]$ is obtained, which substituted in equation 3 affords the ratio between non-rearranged ( $\mathrm{RH}$ $+\mathrm{RAH})$ to rearranged products (R'H + $\mathrm{R}^{\prime} \mathrm{AH}$ ) (equation 5). The ratio expressed in equation 5 is, as expected, solely dependent on the ratio of reaction rates immediately following the generation of the primary radical $\mathrm{R} \cdot$ by dissociative ET. ${ }^{22,23}$ Since we are only interested in the coupling products, we mathematically split equation 5 in its two components, ${ }^{24}$ which are the reduction step (equation 6) and the coupling step (equation $7)$, and focus in the last one.

$$
\begin{aligned}
& \frac{d[\mathrm{RH}+\mathrm{RAH}]}{d t}=\left(k_{r e d}+k_{c o u p l}\right)[\mathrm{Li} \times \mathrm{A}][\mathrm{R} \cdot] \\
& \frac{d\left[\mathrm{R}^{\prime} \mathrm{H}+\mathrm{R}^{\prime} \mathrm{AH}\right]}{d t}=\left(k_{r e d}+k_{\text {coupl }}\right)[\mathrm{Li} \mathrm{x} \mathrm{A}]\left[\mathrm{R}^{\prime} \cdot\right] \\
& \text { hence, } \frac{d[\mathrm{RH}+\mathrm{RAH}]}{d\left[\mathrm{R}^{\prime} \mathrm{H}+\mathrm{R}^{\prime} \mathrm{AH}\right]}=\frac{[\mathrm{R} \cdot]}{\left[\mathrm{R}^{\prime} \cdot\right]} \\
& \text { and from the SSA, } \\
& \frac{d\left[\mathrm{R}^{\prime} \cdot\right]}{d t}=k_{r}[\mathrm{R} \cdot]-\left(k_{\text {red }}+k_{\text {coupl }}\right)[\mathrm{Lix} \mathrm{A}]\left[\mathrm{R}^{\prime} \cdot\right]=0 \\
& \text { therefore } \\
& \frac{[\mathrm{RH}+\mathrm{RAH}]}{\left[\mathrm{R}^{\prime} \mathrm{H}+\mathrm{R}^{\prime} \mathrm{AH}\right]}=\frac{k_{\text {red }}+k_{\text {coupl }}}{k_{r}}[\mathrm{LixA}]
\end{aligned}
$$$$
\text { which splits into }
$$$$
\frac{[\mathrm{RH}]}{\left[\mathrm{R}^{\prime} \mathrm{H}\right]}=\frac{k_{\text {red }}+k_{\text {coupl }}}{k_{r}}[\mathrm{Lix} \mathrm{A}] \text {, and }
$$$$
\frac{[\mathrm{RAH}]}{\left[\mathrm{R}^{\prime} \mathrm{AH}\right]}=\frac{k_{\text {red }}+k_{\text {coupl }}}{k_{r}}[\mathrm{Lix} \mathrm{A}]
$$

The distribution of the reduction products shown in equation 6 was already studied in the past and is consistent with two consecutive ET steps. ${ }^{10}$ The rate constants of reduction of the primary hex-5-enyl radical (R·) with $\mathrm{NaNp}$ and $\mathrm{NaBp}$ were estimated as 
$k_{\text {red }}(\mathrm{NaNp})=10^{9} \mathrm{M}^{-1} \mathrm{~s}^{-1}$ and $k_{\text {red }}(\mathrm{NaBp})=$ $1.610^{9} \mathrm{M}^{-1} \mathrm{~s}^{-1}$ in $\mathrm{DME}$ at $25^{\circ} \mathrm{C}$. ${ }^{10}$ The rate constants for the radical coupling $\left(k_{\text {coupl }}\right)$ were not directly evaluated in that work, which was focused only on reduction products. $^{25}$ But the combined yields of reduction $\left(\mathrm{RH}+\mathrm{R}^{\prime} \mathrm{H}\right)$ was $c a$. $50 \%$ $( \pm 10 \%),{ }^{10 a, b}$ the remaining $50 \%$ being described as mixtures of alkylated dihydroarenes $\left(\mathrm{RAH}+\mathrm{R}^{\prime} \mathrm{AH}\right)$. The coupling of the radical anions with $R \cdot$ and $R^{\prime}$ ' to eventually afford alkylation products RAH and $\mathrm{R}^{\prime} \mathrm{AH}$ is in direct competition with the reduction to carbanions and eventual formation of $\mathrm{RH}$ and $\mathrm{R}$ 'H. Since both types of compounds (reduction and alkylation) are observed in the reaction crudes, the corresponding $k_{\text {coupl }}$ must be of the same order as $k_{\text {red, }}$, therefore the rate of radicalradical anion coupling is straightforward, $k_{\text {coupl }} \cong 10^{9} \mathrm{M}^{-1} \mathrm{~s}^{-1} \cdot{ }^{26} \mathrm{We}$ have to point out in here that these rate constants have not been explicitly determined for the lithium derivatives (LiNp and LiBp) due to excessive dispersion of data. ${ }^{10 \mathrm{~b}, 26}$ Still, we decided to use the rate constants measured for the sodium derivatives as a good estimate for our purposes (Table 1, tablenote c). Notice that these rate constants are very large, near diffusion control. One further step forward would be considering the most demanding scenario, i.e., a diffusion controlled reaction. Let's analyze this scenario in detail. The theoretical estimate of a bimolecular rate constant for a diffusion controlled reaction is given by: $k_{\mathrm{D}}=4 \pi N_{\mathrm{A}}\left(D_{\mathrm{A}}+D_{\mathrm{B}}\right)\left(r_{\mathrm{A}}+r_{\mathrm{B}}\right)$, where $D_{\mathrm{A}}$ and $D_{\mathrm{B}}$ are the diffusion coefficients and $r_{\mathrm{A}}$ and $r_{\mathrm{B}}$ are the reaction radii of the molecules $A$ and $B$. In the absence of diffusion coefficient data, it is common to use the Stokes-Einstein equation relating the diffusion coefficient to the viscosity $\eta$ of the solvent: $D_{\mathrm{A}}=k_{\mathrm{B}} T / 6 \pi \eta r_{\mathrm{A}}, D_{\mathrm{B}}=k_{\mathrm{B}} T / 6 \pi \eta r_{\mathrm{B}}$, and to identify the diffusion radii with the radii for reaction of $(A+B)$. Combination of these two equations affords a simple expression: $k_{\mathrm{D}}=8 R T / 3 \eta$. For radical coupling, (i.e., for $k_{\text {coupl }}=k_{\mathrm{D}}$ ) only radical pairs which are in the singlet state during the encounter lead to the reaction products, therefore there is an additional statistical factor of $\sigma=1 / 4$ to be accounted for too. In our case for $\mathrm{THF}$ at $25^{\circ} \mathrm{C}(\eta=0.456 \mathrm{mPa} \cdot \mathrm{s})$, $k_{\mathrm{D}}=3.62 \cdot 10^{9} \mathrm{M}^{-1} \mathrm{~s}^{-1}$, and likewise for $\mathrm{DME}$ at $25^{\circ} \mathrm{C}(\eta=0.455 \mathrm{mPa} \cdot \mathrm{s}), k_{\mathrm{D}}=3.63 \cdot 10^{9}$ $\mathrm{M}^{-1} \mathrm{~s}^{-1} \quad$ (Table 1 , tablenote $\mathrm{d}$ ). ${ }^{27}$ The conclusions drawn in this paper are based on the lack of rearranged products. As we shall evidence quantitatively below (Table 1), they are incontrovertible for the cyclopropylmethyl probe, since the opposite would require rates of coupling way beyond the diffusion control limit. All together reduction and coupling make out of the naphthalene and biphenyl radical anions and dianions some excellent radical traps, keeping the concentration of $[\mathrm{R} \cdot]$ and $\left[\mathrm{R}^{\prime} \cdot\right]$ low and thus validating the steady state approximation used in equation 4. The remaining required kinetic data is well reported. The unimolecular rearrangement of $\mathrm{R} \cdot \rightarrow \mathrm{R}$ ' is barely dependent on the solvent and occurs with a rate constant $k_{\mathrm{r}}$ (hex-5enyl) $=10^{5} \mathrm{~s}^{-1}$ at $25^{\circ} \mathrm{C} .^{28}$ For the cyclopropylmethyl radical, the rearrangement is much faster, $k_{\mathrm{r}}$ (cyclopropylmethyl) $=10^{8}$ $\mathrm{s}^{-1}$ at $25^{\circ} \mathrm{C} .^{29,30}$ The application of equation 7 to our set of experimental conditions is collected in Table 1. 


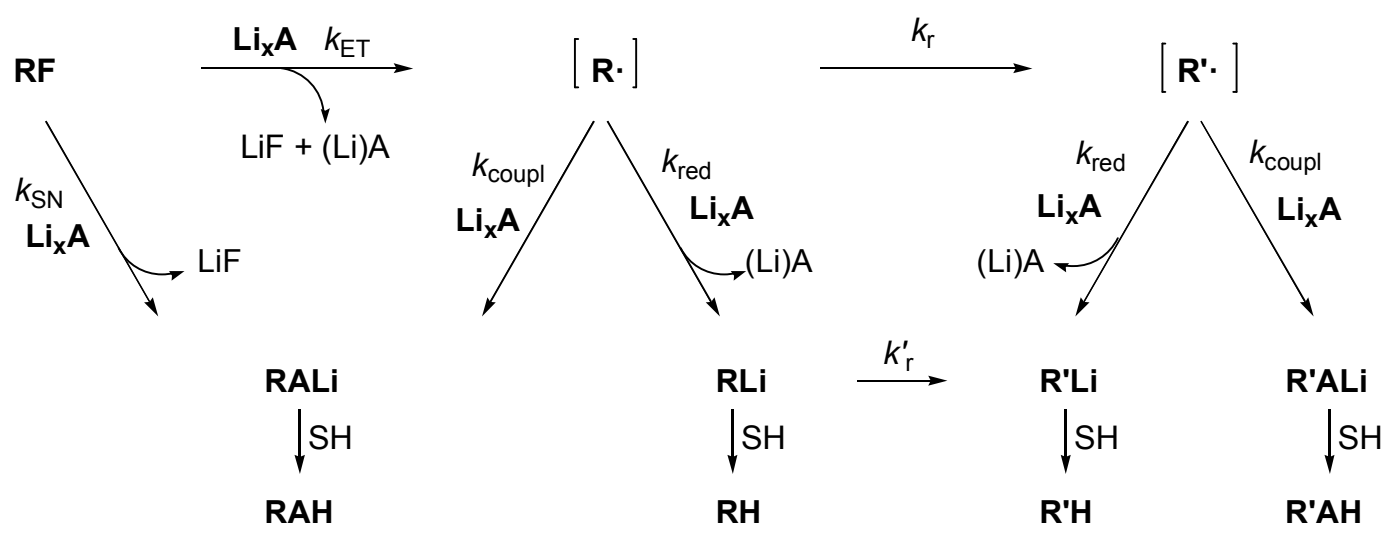

Scheme 4. Overall reaction network, including both $\mathrm{S}_{\mathrm{N}}\left(k_{\mathrm{SN}}\right)$ and $\mathrm{ET}\left(k_{\mathrm{ET}}\right)$ reaction pathways, as well as the rest of events following ET. The ET reagent has been represented as $\mathrm{Li}_{\mathrm{x}} \mathrm{A}$, with $\mathrm{A}=\mathrm{Np}, \mathrm{Bp}$, and $1 \leq \mathrm{x} \leq 2$, indicating a undetermined mixture of radical anion and dianion. $\mathrm{R}=$ non rearranged framework, $\mathrm{R}^{\prime}=$ rearranged framework. The corresponding hydrocarbon products are generated in a final protonation step $\left(\mathrm{SH}=\mathrm{H}_{2} \mathrm{O}\right.$ or solvent).

The results shown in Table 1 make clear a number of things about the reactions of Schemes 2 and 3. The experiments reported so far using hex-5-enyl fluoride (1b) as a radical probe probed to be inconclusive. For this probe, the calculated $\mathrm{RAH} / \mathrm{R}$ 'AH ratio would be too large to be measured experimentally under any of the experimental conditions assayed. In the most favourable case $\left(0.01 \mathrm{M} \mathrm{Li}_{\mathrm{x}} \mathrm{Np}\right.$ whit $\left.\mathbf{1 b}\right)$ the ratio $(200: 1)$ is twice the detection limit. The scenery is very different for the cyclopropylmethyl fluoride (1a). The calculated RAH/R'AH ratio assuming radical coupling should be easily measured by GLC, or even by a less precise quantitative techniques such as ${ }^{1} \mathrm{H}$ NMR. ${ }^{13}$ Moreover, the rearranged compound R'AH should be the mayor component in most instances. However this is not the case, since rearranged products R'AH remain undetectable under all the experimental conditions. Even in the limiting case of a hypothetical diffusion controlled reaction of $\mathrm{Li}_{\mathrm{x}} \mathrm{A}$ with the free radical $\mathrm{R} \cdot$, the expected ratio $\mathrm{RAH} / \mathrm{R}^{\prime} \mathrm{AH} \mathrm{H}_{\text {diffuss. }}$ is expected to fall within the normal measurable range of most techniques (from 7.2:1 to $0.7: 1$ depending on the assayed concentrations). Concerning unwanted metal-solution interface effects, Mattalia and co-workers raised attention to the issue that it was no easy to rationalize the amount of rearranged/non rearranged products in reactions involving metallic surfaces and radical probes. ${ }^{31}$ To circumvent this problem, reactions in this work were carried out after centrifugation of the metal excess from the reaction media, so only the homogeneous phase containing $\mathrm{Li}_{\mathrm{x}} \mathrm{A}$ in solution in the absence of $\mathrm{Li}_{(\mathrm{s})}$ is responsible for the reported results. It should be pointed out that the reaction fails to afford alkylation products with cyclopropylmethyl chloride or bromide. Only low mw hydrocarbons are obtained by an ET process. ${ }^{32}$ 
Table 1. Calculated and experimental ratio of non-rearranged $(\mathrm{RAH})$ to rearranged $\left(\mathrm{R}^{\prime} \mathrm{AH}\right)$ alkylation products under different Li $\mathrm{i}_{\mathrm{x}} \mathrm{A}$ concentrations. ${ }^{a}$

\begin{tabular}{|c|c|c|c|c|c|}
\hline \multirow[b]{2}{*}{$\mathrm{RF}^{\mathrm{a}}$} & \multirow[b]{2}{*}[\mathrm{Li}_{\mathrm{x}}\mathrm{A}]{$^{\mathrm{b}}(\mathrm{M})$} & \multirow{2}{*}{$\frac{[\mathrm{RAH}]}{\left[\mathrm{R}^{\prime} \mathrm{AH}\right]_{\text {calc. }}{ }^{\mathrm{c}}}$} & \multirow{2}{*}{$\frac{[\mathrm{RAH}]}{\left[\mathrm{R}^{\prime} \mathrm{AH}\right]_{\text {diffus. }}}$} & $\underline{[\mathrm{RAH}]}$ & \multirow{2}{*}{ Compounds $^{f}$} \\
\hline & & & & $\mathrm{e}^{\left[\mathrm{R}^{\prime} \mathrm{AH}\right]}$ expt. & \\
\hline \multirow{12}{*}{ 1a } & $0.1 \mathrm{M} \mathrm{Li}_{\mathrm{x}} \mathrm{Np}$ & 2000:1 & $7200: 1$ & $\begin{array}{c}\mathbf{3 b} / \mathbf{3 b} \\
>100: 1\end{array}$ & \\
\hline & $0.05 \mathrm{M} \mathrm{Li}_{\mathrm{x}} \mathrm{Np}$ & 1000:1 & 3600:1 & $>100: 1$ & \\
\hline & $0.01 \mathrm{M} \mathrm{Li}_{\mathrm{x}} \mathrm{Np}$ & $200: 1$ & $720: 1$ & $>100: 1$ & \\
\hline & $0.1 \mathrm{M} \mathrm{Li}_{\mathrm{x}} \mathrm{Bp}$ & $3200: 1$ & $7200: 1$ & $\begin{array}{c}\mathbf{4 b} / \mathbf{4 b} \\
>100: 1\end{array}$ & \\
\hline & $0.05 \mathrm{M} \mathrm{Li}_{\mathrm{x}} \mathrm{Bp}$ & 1600:1 & $3600: 1$ & $>100: 1$ & \\
\hline & $0.01 \mathrm{M} \mathrm{Li}_{\mathrm{x}} \mathrm{Bp}$ & $320: 1$ & $720: 1$ & $>100: 1$ & \\
\hline & $0.1 \mathrm{M} \mathrm{Li}_{\mathrm{x}} \mathrm{Np}$ & $2: 1$ & $7.2: 1$ & $\begin{array}{l}\mathbf{3 a} / \mathbf{3 a} \mathbf{a}^{\prime} \\
>100: 1\end{array}$ & \\
\hline & $0.05 \mathrm{M} \mathrm{Li}_{\mathrm{x}} \mathrm{Np}$ & $1: 1$ & $3.6: 1$ & $>100: 1$ & \\
\hline & $0.01 \mathrm{M} \mathrm{Li}_{\mathrm{x}} \mathrm{Np}$ & $0.2: 1$ & $0.7: 1$ & $>100: 1$ & \\
\hline & $0.1 \mathrm{M} \mathrm{Li}_{\mathrm{x}} \mathrm{Bp}$ & $3.2: 1$ & $7.2: 1$ & $\begin{array}{l}\mathbf{4 a} / \mathbf{4 a} \mathbf{a}^{\prime} \\
>100 \cdot 1\end{array}$ & \\
\hline & $0.05 \mathrm{M} \mathrm{Li}_{\mathrm{x}} \mathrm{Bp}$ & $1.6: 1$ & $3.6: 1$ & $>100: 1$ & \\
\hline & $0.01 \mathrm{M} \mathrm{Li}_{\mathrm{x}} \mathrm{Bp}$ & $0.32: 1$ & $0.7: 1$ & $>100: 1$ & \\
\hline
\end{tabular}

${ }^{a}$ The reactions were performed by addition of probes $\mathbf{1 b}$ and $\mathbf{1 a}$ to an excess of $\mathrm{Li}_{\mathrm{x}} \mathrm{A}$ of a given formal concentration in $\mathrm{THF}$ (Li $\mathrm{Bp}$ ) or THP $\left(\mathrm{Li}_{\mathrm{x}} \mathrm{Np}\right)$ both at $0^{\circ} \mathrm{C}$ and $25^{\circ} \mathrm{C}$ followed by hydrolysis. Molar ratio $\mathrm{Li}_{\mathrm{x}} \mathrm{A}$ to $\mathrm{RF}=10: 1$. About 4-5 experiments of each kind were run with nearly identical ratios. ${ }^{b}$ Formal concentration of $\left[\mathrm{Li}_{\mathrm{x}} \mathrm{A}\right]$, with $\mathrm{A}=\mathrm{Np}, \mathrm{Bp}$, and $1 \leq \mathrm{x} \leq 2$, indicating a undetermined mixture of radical anion and dianion. ${ }^{\mathrm{c}}$ Calculated using equation 7 as explained in the text. ${ }^{\mathrm{d}}$ Ratio assuming diffusion controlled rates for $k_{\text {red }}$ and $k_{\text {coupl }}$ at $25^{\circ} \mathrm{C}$. ${ }^{\mathrm{e}}$ We set a sensitivity threshold for the simultaneous measurement of both isomers by GLC as $\leq 100: 1$. In all cases, no traces of rearranged product were detected by GLC. This was contrasted with a sample of the actual rearranged alkylation product (3a', 4a', $\mathbf{3 b}$ 'and 4b') synthesized for that purpose (see experimental). The cyclobutyl derivatives 3a" and 4a' are not produced in these type of reactions (scheme 2 and 3). ${ }^{\mathrm{f}}$ Complete structural elucidation $\left({ }^{1} \mathrm{H}-\mathrm{NMR},{ }^{13} \mathrm{C}-\mathrm{NMR}, \mathrm{IR}, \mathrm{MS}, \mathrm{HRMS}\right)$ of all alkylation compounds can be found in the experimental and supplementary information. From the distribution of reduction and alkylation products, $k_{\text {red }} \cong k_{\text {coupl }}$ for $\mathbf{1 b}$ and $k_{\text {red }} \cong 7 k_{\text {coupl }}$ for $1 \mathbf{a}$.

\section{CONCLUSIONS}

A kinetic study of the alkylation of the dianion of naphthalene and biphenyl as lithium salts was carried out with the help of the very fast radical probe cyclopropylmethyl fluoride (1a). To investigate in detail the composition of the reaction crudes, the whole set of potential rearranged and unrrearranged alkylation products was synthetized and were used as controls. Analysis by GLC showed that, to 
the limit of detection, the reaction crudes contained only unrearranged alkylated arenes. The observed distribution of products anticipates a mechanism of alkylation different from the classical one (which involves ET followed by coupling between diffusing radicals and arene radical-anions), and supports a concerted mechanism such as the $S_{N} 2$. These results overtake less conclusive former studies with slower radical probes such as hex-5enyl fluoride (1b) that, although pointed out to the same conclusions, would not stand a rigorous quantitative test.

\section{EXPERIMENTAL SECTION}

\section{General information}

Synthesis and spectroscopic description of cyclopropylmethyl 4-methylbenzenesulfonate (2a).

A solution of cyclopropylmethanol (7.247 g, 100 $\mathrm{mmol})$ and dimethylaminopyridine $(0.617 \mathrm{~g}, 5$ $\mathrm{mmol})$ in triethylamine $(50 \mathrm{ml})$ was added to a solution of $p$-toluenesulfonyl chloride $(22.98 \mathrm{~g}, 120$ mmol) in dichloromethane $(60 \mathrm{ml})$ at $0^{\circ} \mathrm{C}$, under a dry atmosphere (Ar). The mixture was stirred at $0^{\circ} \mathrm{C}$ for $12 \mathrm{~h}$. After this time, the reaction crude was poured on a mixture of crushed ice and concentrated sulfuric acid, and was extracted with dichloromethane $(3 \times 30 \mathrm{ml})$ maintaining ice-cold temperatures at all times. The organic phase was dried with sodium sulfate and the solvent was removed under reduced pressure at $15^{\circ} \mathrm{C}$. The resulting crude cyclopropylmethy tosylate is pure and can be used without further purification. Addition of a carefully weighed amount of an internal standard (hexamethylbenzene) revealed a yield of $96 \%$ of pure $2 \mathrm{a}(>99 \%)$, as determined by $400 \mathrm{MHz}{ }^{1} \mathrm{H}$ NMR.

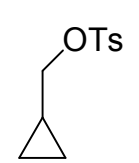

Cyclopropylmethyl

$4-$

methylbenzenesulfonate (2a). Obtained in this way, 2a is a low melting point white solid $\left(\mathrm{mp}=16-17^{\circ} \mathrm{C}\right.$, uncorrected), $R_{\mathrm{f}}=0.56$ (hexane/ethyl acetate 95:5); IR (film): $v\left(\mathrm{~cm}^{-1}\right)=3045,1597$, $1356,1171,1096,1026,924,842,813,781 ;{ }^{1} \mathrm{H}$ NMR $\left(300 \mathrm{MHz}, \mathrm{CDCl}_{3}, 25^{\circ} \mathrm{C}, \mathrm{TMS}\right): \delta_{\mathrm{H}}=0.20-$ 0.29 (m, $2 \mathrm{H}, 2 \times \mathrm{CH} \mathrm{H}$ of cyclopropane), 0.53-0.63 (m, $2 \mathrm{H}, 2 \times \mathrm{CH} H$ of cyclopropane), 1.04-1.19 (m, $1 \mathrm{H}, \mathrm{CH}$ of cyclopropane), $3.90\left(\mathrm{~d},{ }^{3} J(\mathrm{H}, \mathrm{H})=7.4\right.$ $\left.\mathrm{Hz}, 2 \mathrm{H}, \mathrm{OCH}_{2} \mathrm{CH}\right), 7.35\left(\mathrm{~d},{ }^{3} \mathrm{~J}(\mathrm{H}, \mathrm{H})=8.3 \mathrm{~Hz}, 2 \mathrm{H}\right.$, aromatic $\mathrm{H}), 7.81\left(\mathrm{~d},{ }^{3} J(\mathrm{H}, \mathrm{H})=8.3 \mathrm{~Hz}, 2 \mathrm{H}\right.$, aromatic $\mathrm{H}) ;{ }^{13} \mathrm{C}$ NMR $\left(75 \mathrm{MHz}, \mathrm{CDCl}_{3}, 25^{\circ} \mathrm{C}\right.$, TMS): $\delta_{\mathrm{C}}=3.86\left(2 \times \mathrm{CH}_{2}\right.$ of cyclopropane $), 10.02$
( $\mathrm{CH}$ of cyclopropane), $21.79\left(\mathrm{CH}_{3}\right), 76.03\left(\mathrm{OCH}_{2}\right)$, 127.99 (arom. CH), 129.92 (arom. CH), 133.63 $\left(\mathrm{CCH}_{3}\right), 144.72(\mathrm{CS}) ; \mathrm{MS}(70 \mathrm{eV}): \mathrm{m} / z(\%): 228$ (0.14) $\left[M^{+}+2\right], 227(0.35)\left[M^{+}+1\right], 226(1.80)\left[M^{+}\right]$, 198 (24), 155 (95), 92 (15), 91 (100), 65 (21).

Synthesis and spectroscopic description of cyclopropylmethyl fluoride (1a).

The synthesis was performed in a dry two-neck 100 $\mathrm{ml}$ flask containing a Teflon-coated stirrer bar and connected to a cold trap. One neck was capped with a rubber septum, the second was glass connected to a cold trap using conical joints and this last to a bubbler. The apparatus was evacuated with argon, the flask was cooled to $0^{\circ} \mathrm{C}$ and the trap at $-80^{\circ} \mathrm{C}$. Solid cyclopropylmethyl $p$-toluenesulfonate (2a, $3.620 \mathrm{~g}, 16 \mathrm{mmol})$ was placed in the flask and a solution of tetrabutylammonium fluoride (TBAF $1 \mathrm{M}$ in $\mathrm{THF}$ at $0^{\circ} \mathrm{C}, 20 \mathrm{ml}$ ) was added with stirring while maintaining everything between $0-5^{\circ} \mathrm{C}$. A gentle stream of argon was bubled through the reaction mixture using a needle and the volatile material 1a was allowed to distil from the reaction mixture and collected in the cold trap. The distilled fluorinated material was $93 \%$ cyclopropylmethyl fluoride (1a), along with $4.4 \%$ of cyclobutyl fluoride (1a') and a $2.6 \%$ of homoallyl fluoride (1a') in THF in an overall $22-25 \%$ yield. The crude distillate was treated with a slight excess of bromine ( 3 mole \%) and distilled again to afford $>95 \%$ pure $1 \mathbf{a}$ in the strict absence of unwanted 1a'. Alternatively, $\mathrm{CHCl}_{3}$ could be used as solvent instead of THF.

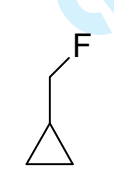

Cyclopropylmethylfluoride (1a): ${ }^{1} \mathrm{H}$ NMR (300 $\left.\mathrm{MHz}, \mathrm{CDCl}_{3},-20^{\circ} \mathrm{C}, \mathrm{TMS}\right): \delta_{\mathrm{H}}=$ 0.18-0.35 (m, $2 \mathrm{H}, \quad 2 \times \mathrm{CH} \mathrm{H} \quad$ of cyclopropane), $0.49-0.66(\mathrm{~m}, 2 \mathrm{H}, 2 \times \mathrm{CH} H$ of cyclopropane), 1.09-1.30 (m, $1 \mathrm{H}, \mathrm{CH}$ of cyclopropane), $4.19\left(\mathrm{dd},{ }^{2} J(\mathrm{~F}, \mathrm{H})=48.9 \mathrm{~Hz},{ }^{3} J(\mathrm{H}, \mathrm{H})\right.$ $\left.=7.5 \mathrm{~Hz}, 2 \mathrm{H}, \mathrm{FCH}_{2} \mathrm{CH}\right) ;{ }^{13} \mathrm{C} \mathrm{NMR}(75 \mathrm{MHz}$, $\left.\mathrm{CDCl}_{3}, 25^{\circ} \mathrm{C}, \mathrm{TMS}\right): \delta_{\mathrm{C}}=2.82\left(\mathrm{~d},{ }^{3} J(\mathrm{~F}, \mathrm{C})=6.9 \mathrm{~Hz}\right.$, $2 \mathrm{C}, 2 \times \mathrm{CH}_{2}$ of cyclopropane), $10.97\left(\mathrm{~d},{ }^{2} J(\mathrm{~F}, \mathrm{C})=\right.$ $25.2 \mathrm{~Hz}, C \mathrm{H}$ of cyclopropane $), 88.51\left(\mathrm{~d},{ }^{1} J(\mathrm{~F}, \mathrm{C})=\right.$ $165.7 \mathrm{~Hz}, \mathrm{FCH}_{2}$ ).

Kinetic experiments: Reaction of the fluorinated probes 1a and $\mathbf{1 b}$ with $L i_{x} N p$ and $L i_{x} B p$. Solutions of the given formal concentrations of $\mathrm{Li}_{\mathrm{x}} \mathrm{Np}$ in THP, ${ }^{9}, 2,8 \mathrm{~b}$ and $\mathrm{Li}_{\mathrm{x}} \mathrm{Bp}$ in THF, ${ }^{2,8 \mathrm{a}}$ were prepared as usual under argon using a large excess of lithium powder (ca. 10:1 Li:A molar ratio) and the corresponding weighted arene with stirring at $0^{\circ} \mathrm{C}$ during 1 hour. These suspensions were centrifuged ( $2500 \mathrm{rpm}, 2 \mathrm{~min}$ ) at the same temperature to remove the excess metal and the corresponding probe $3 \mathrm{a}$ or $3 \mathrm{~b}$ diluted in THF ( $c a$. 10:1) was slowly injected into the deeply colored solution of the dianions (dark purple for $\mathrm{Li}_{\mathrm{x}} \mathrm{Np}$ and dark greenish-blue for $\mathrm{Li}_{\mathrm{x}} \mathrm{Bp}$; 
molar ratio $\left.\mathrm{Li}_{\mathrm{x}} \mathrm{A}: \mathrm{RF} \approx 10: 1\right)$ at $25^{\circ}$ and $0^{\circ} \mathrm{C}$. After 30 $\mathrm{min}$, the reaction was hydrolized with acetonitrile $(1 \mathrm{ml})$ followed by water $(5 \mathrm{ml})$ and neutralized. Hydroquinone $(10 \mathrm{mg})$ was added as stabilizing, ${ }^{1 \mathrm{c}}$ and it was extracted with diethyl ether $(3 \times 20 \mathrm{ml})$ and dried over $\mathrm{Na}_{2} \mathrm{SO}_{4(\mathrm{~s})}$. Samples were submitted to GLC analysis. In the case of naphthalene derivatives, they were rearomatized with a slight excess of DDQ at room temperature overnight, washed with $1 \mathrm{M} \mathrm{NaOH}$ and submitted to GLC analysis. In all cases, pure isolated 3a, 3a', 3a', 3b, 3b', as well as $\mathbf{4 a}, \mathbf{4 a}$ ', 4a", $4 \mathbf{b}$ and $4 \mathbf{b}^{\prime}$ ' were used as control.

Synthesis and spectroscopic description of alkylated

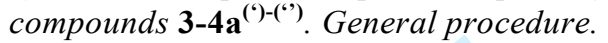

For the alkylation of $\mathrm{Li}_{x} \mathrm{~Np}$ and $\mathrm{Li}_{\mathrm{x}} \mathrm{Bp}$ and subsequent isolation of products, we used a procedure similar to that described in Kinetic experiments section above, but using a stoichiometric ratio of reagents at a lower reaction temperature to enhance $\mathrm{S}_{\mathrm{N}}$ over ET products. A suspension of lithium powder $\left(\mathrm{Li}_{(\mathrm{s})}, 70 \mathrm{mg}, 10\right.$ mmol) and the corresponding arene (naphthalene, $256.4 \mathrm{mg}, 2 \mathrm{mmol}$; or biphenyl, $308.5 \mathrm{mg}, 2 \mathrm{mmol}$ ) in a dry ethereal solvent $(10 \mathrm{ml})$ (tetrahydropyran was used in the case of naphthalene while tetrahydrofuran was used in the case of biphenyl) was allowed to stir magnetically for $1 \mathrm{~h}$ at $0^{\circ} \mathrm{C}$ under Ar atmosphere. These deeply colored suspensions were further cooled down to $-40^{\circ} \mathrm{C}$ (for $\mathrm{Li}_{\mathrm{x}} \mathrm{Np}$ ) or $-80^{\circ} \mathrm{C}$ (for $\mathrm{Li}_{\mathrm{x}} \mathrm{Bp}$ ) and the corresponding alkyl fluoride 1a, 1a' or 1a'" $(2 \mathrm{mmol})$ diluted in THF (1 $\mathrm{ml}$ ) was slowly injected to the suspension of the dianions at the same temperature. ${ }^{33}$ After $30 \mathrm{~min}$, the reaction was hydrolized with acetonitrile $(1 \mathrm{ml})$ followed by water $(5 \mathrm{ml})$, the temperature was raised to $\mathrm{rt}$ and the mixture was neutralized with $\mathrm{HCl} 3 \mathrm{M}$. Hydroquinone $(10 \mathrm{mg})$ was added as stabilizing, the crude was extracted with diethyl ether $(3 \times 20 \mathrm{ml})$ and dried over $\mathrm{Na}_{2} \mathrm{SO}_{4(\mathrm{~s})}$. In the case of naphthalene derivatives, they were rearomatized with a slight excess of DDQ at room temperature overnight, washed with $1 \mathrm{M} \mathrm{NaOH}$ and dried over $\mathrm{Na}_{2} \mathrm{SO}_{4(\mathrm{~s})}$. The solvent was removed by rotatory evaporation (15 Torr) and the resulting residue was purified by column chromatography (silica gel doped with a $5 \%$ of hidroquinone, hexane/ethyl acetate). Yields: 3a $50 \%$; 3a' $55 \%$; 4a $55 \%$; 4a' $63 \%$.

1-Cyclopropylmethylnaphthalene (3a): $R_{\mathrm{f}}=0.49$<smiles>c1ccc2c(CC3CC3)cccc2c1</smiles>
(hexane); IR (film): $v\left(\mathrm{~cm}^{-1}\right)=$ 3074, 3009, 2923, 2850, 1639, $1598,1513,1463,1399,1272$, 1093, 1020, 914, 832, 791, 771, 734, 645; ${ }^{1} \mathrm{H}$ NMR $(300 \mathrm{MHz}$, $\left.\mathrm{CDCl}_{3}, 25^{\circ} \mathrm{C}, \mathrm{TMS}\right): \delta_{\mathrm{H}}=0.14-$ $0.38(\mathrm{~m}, 2 \mathrm{H}, 2 \times \mathrm{CH} \mathrm{H}$ of cyclopropane), $0.48-0.66$ (m, $2 \mathrm{H}, 2 \times \mathrm{CH} H$ of cyclopropane), 1.08-1.27 (m, $1 \mathrm{H}, \mathrm{CH}$ of cyclopropane), $3.01\left(\mathrm{~d},{ }^{3} \mathrm{~J}(\mathrm{H}, \mathrm{H})=6.7\right.$ $\left.\mathrm{Hz}, 2 \mathrm{H}, \mathrm{CH}_{2} \mathrm{CH}_{\text {cyclopropane }}\right), 7.33-7.60\left(\mathrm{~m}, 4 \mathrm{H}, \mathrm{CH}_{\mathrm{ar}}\right)$ , 7.73 (app d, $\left.J=7.8 \mathrm{~Hz}, 1 \mathrm{H}, \mathrm{CH}_{\mathrm{ar}}\right), 7.78-7.93(\mathrm{~m}$, $1 \mathrm{H} \mathrm{CH}$ ar $), 8.00-8.14\left(\mathrm{~m}, 1 \mathrm{H}, \mathrm{CH}_{\mathrm{ar}}\right) ;{ }^{13} \mathrm{C}$ NMR $(75$ $\left.\mathrm{MHz}, \mathrm{CDCl}_{3}, 25^{\circ} \mathrm{C}, \mathrm{TMS}\right): \delta_{\mathrm{C}}=5.26\left(2 \mathrm{C}, 2 \times \mathrm{CH}_{2}\right.$ of cyclopropane), 11.13 (CH of cyclopropane), 37.28 $\left(\mathrm{CH}_{2} \mathrm{CH}_{\text {cyclopropane }}\right), 123.96,125.53,125.64,125.74$, $125.82,126.68,128.81\left(7 \times \mathrm{CH}_{\mathrm{ar}}\right), 132.23,133.84$ $\left(2 \times \mathrm{C}_{\mathrm{ar}}\right), 138.18\left(\mathrm{C}_{\mathrm{ar}} \mathrm{CH}_{2}\right) ; \mathrm{MS}(70 \mathrm{eV}): \mathrm{m} / z(\%): 185$ $\begin{array}{lllllll}(0.02) & {\left[M^{+}+3\right],} & 184 & (0.43) & {\left[M^{+}+2\right],} & 183 & (6.19)\end{array}$ $\left[M^{+}+1\right], 182(39.51)\left[M^{\square}\right], 167(29), 166(6), 165$ (14), 154 (18), 153 (35), 152 (19), 142 (12), 141 (100), 115 (22); HRMS: (EI) $\mathrm{m} / z$ calcd for $\mathrm{C}_{14} \mathrm{H}_{14}$ 182.1095 , found 182.1089 .

1-(3-Butenyl)naphthalene (3a'): $R_{\mathrm{f}}=0.48$ (hexane);

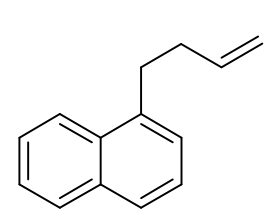
IR (film): $v\left(\mathrm{~cm}^{-1}\right)=3070$, $3005,2948,2846,1440,1260$, $1085,1032,914,791,771 ;{ }^{1} \mathrm{H}$ NMR (300 $\mathrm{MHz}, \mathrm{CDCl}_{3}$, $\left.25^{\circ} \mathrm{C}, \mathrm{TMS}\right): \delta_{\mathrm{H}}=2.51(\mathrm{app}$ $\mathrm{td},{ }^{3} J(\mathrm{H}, \mathrm{H})=7.9 \mathrm{~Hz},{ }^{3} J(\mathrm{H}, \mathrm{H})$ $\left.=7.2 \mathrm{~Hz}, 2 \mathrm{H}, \mathrm{CH}_{2} \mathrm{CH}_{2} \mathrm{CH}=\mathrm{CH}_{2}\right), 3.17$ (app t, $\left.{ }^{3} J(\mathrm{H}, \mathrm{H})=7.9 \mathrm{~Hz}, 2 \mathrm{H}, \mathrm{C}_{\mathrm{ar}} \mathrm{CH}_{2} \mathrm{CH}_{2}\right) ; 5.02($ app d, $\left.{ }^{3} J(\mathrm{H}, \mathrm{H})=10.2 \mathrm{~Hz}, 1 \mathrm{H}, \mathrm{CH}=\mathrm{CH} H\right), 5.10($ app d, ${ }^{3} J(\mathrm{H}, \mathrm{H})=17.1 \mathrm{~Hz},{ }^{3} J(\mathrm{H}, \mathrm{H})=1.6 \mathrm{~Hz}, 1 \mathrm{H}$, $\mathrm{CH}=\mathrm{C} H \mathrm{H}), 5.97 \quad\left(\right.$ app ddt, ${ }^{3} J(\mathrm{H}, \mathrm{H})=16.8 \mathrm{~Hz}$, ${ }^{3} J(\mathrm{H}, \mathrm{H})=10.2 \mathrm{~Hz},{ }^{3} J(\mathrm{H}, \mathrm{H})=6.6 \mathrm{~Hz}, 1 \mathrm{H}$, $\left.\mathrm{CH}_{2} \mathrm{CH}=\mathrm{CH}_{2}\right), 7.30-7.56\left(\mathrm{~m}, 4 \mathrm{H}, \mathrm{CH}_{\mathrm{ar}}\right), 7.72(\mathrm{~d}$, $\left.{ }^{3} J(\mathrm{H}, \mathrm{H})=8.1 \mathrm{~Hz}, 1 \mathrm{H}, \mathrm{CH}_{\mathrm{ar}}\right), 7.82-7.89(\mathrm{~m}, 1 \mathrm{H}$, $\left.\mathrm{CH}_{\mathrm{ar}}\right), 8.04\left(\mathrm{~d},{ }^{3} \mathrm{~J}(\mathrm{H}, \mathrm{H})=7.9 \mathrm{~Hz}, \mathrm{CH}_{\mathrm{ar}}\right) ;{ }^{13} \mathrm{C}-\mathrm{RMN}$ $\left(75 \mathrm{MHz}, \quad \mathrm{CDCl}_{3}, \quad 25^{\circ} \mathrm{C}, \quad \mathrm{TMS}\right): \quad \delta_{\mathrm{C}}=32.62$ $\left(\mathrm{CH}_{2} \mathrm{CH}_{2} \mathrm{CH}=\mathrm{CH}_{2}\right), 34.96\left(\mathrm{C}_{\mathrm{ar}} \mathrm{CH}_{2} \mathrm{CH}_{2}\right), 115.07$ $\left(\mathrm{CH}_{2}=\mathrm{CH}\right), 123.88,125.57,125.66,125.90,126.08$, $126.78,128.93\left(7 \times \mathrm{CH}_{\mathrm{ar}}\right), 131.97,134.01\left(2 \times C_{\mathrm{ar}}\right)$, $138.07\left(C_{\mathrm{ar}} \mathrm{CH}_{2}\right), 138.40\left(\mathrm{CH}=\mathrm{CH}_{2}\right)$; $\mathrm{MS}(70 \mathrm{eV})$ : $\mathrm{m} / z$ (\%): $185(0.01)\left[M^{+}+3\right], 184(0.25)\left[M^{+}+2\right], 183$ (3.61) $\left[M^{+}+1\right], 182(23.55)\left[M^{\square+}\right], 142(12), 141$ (100), 139 (6), 115 (20); HRMS: (EI) $\mathrm{m} / z$ calcd for $\mathrm{C}_{14} \mathrm{H}_{14}$ 182.1096, found 182.1095 .

1-(Cyclobutyl)naphthalene (3a'): $\quad R_{\mathrm{f}}=0.51$<smiles>c1ccc2c(C3CCC3)cccc2c1</smiles>
(hexane); IR (film): $v\left(\mathrm{~cm}^{-1}\right)=$ 3054, 2960, 2932, 2854, 1676, 1594, 1513, 1464, 1264, 1097, 795, $775 ;{ }^{1} \mathrm{H}$ NMR $\left(300 \mathrm{MHz}, \mathrm{CDCl}_{3}\right.$, $\left.25^{\circ} \mathrm{C}, \mathrm{TMS}\right): \delta_{\mathrm{H}}=1.842 .00(\mathrm{~m}, 1 \mathrm{H}$, $\mathrm{CH} H$ of cyclobutane), 2.05-2.42 (m, $3 \mathrm{H}, 3 \times \mathrm{CH} H$ of cyclobutane), 2.47- $2.62(\mathrm{~m}, 1 \mathrm{H}, \mathrm{CH} H$ of cyclobutane $), 4.06-4.25$ (m, 1H, CH of cyclobutane), 7.33-7.40 (app d, $\left.{ }^{3} J(\mathrm{H}, \mathrm{H})=7.1 \mathrm{~Hz}, 1 \mathrm{H}, \mathrm{CH}_{\mathrm{ar}}\right), 7.41-7.53(\mathrm{~m}, 3 \mathrm{H}$, $\left.3 \times \mathrm{CH}_{\mathrm{ar}}\right), 7.70\left(\mathrm{~d},{ }^{3} J(\mathrm{H}, \mathrm{H})=8.1 \mathrm{~Hz}, 1 \mathrm{H}, \mathrm{CH}_{\mathrm{ar}}\right)$, 7.81-7.88 (m, $\left.1 \mathrm{H}, \mathrm{CH}_{\mathrm{ar}}\right), 7.93-8.00\left(\mathrm{~m}, 1 \mathrm{H}, \mathrm{CH}_{\mathrm{ar}}\right)$; ${ }^{13} \mathrm{C}-\mathrm{RMN}\left(75 \mathrm{MHz}, \mathrm{CDCl}_{3}, 25^{\circ} \mathrm{C}, \mathrm{TMS}\right): \delta_{\mathrm{C}}=$ 
$18.83\left(\mathrm{CH}_{2}\right.$ of cyclobutane $), 29.32\left(2 \times \mathrm{CH}_{2}\right.$ of cyclobutane), 38.22 (CH of cyclobutane), 122.56, $124.41,125.53,125.62,125.65,126.42,128.76$ $\left(7 \times \mathrm{CH}_{\mathrm{ar}}\right), 131.65,133.87\left(2 \times \mathrm{C}_{\mathrm{ar}}\right), 141.78\left(C_{\mathrm{ar}} \mathrm{CH}\right.$ of cyclobutane); MS (70eV): $\mathrm{m} / \mathrm{z} \quad(\%): 185 \quad(0.02)$ $\left[M^{+}+3\right], 184(0.40)\left[M^{+}+2\right], 183(5.48)\left[M^{+}+1\right], 182$ (36.03) $\left[M^{\natural}\right] ; 155$ (12), 154 (100), 153 (82), 152 (33); HRMS: (EI) $\mathrm{m} / z$ calcd for $\mathrm{C}_{14} \mathrm{H}_{14} 182.1096$, found 182.1099 .

\section{(1-Cyclopropylmethylcyclohexa-2,5-dienyl)benzene}<smiles>C1=CC(CC2CC2)(c2ccccc2)C=CC1</smiles>

(4a): $R_{\mathrm{f}}=0.47$ (hexane); IR (film): $v\left(\mathrm{~cm}^{-1}\right)=3017,2947,2914,2844$, $1470,1463,1356,1238,1022,944$, $911,735,692 ;{ }^{1} \mathrm{H}$ NMR $(300 \mathrm{MHz}$, $\mathrm{CDCl}_{3}, 25^{\circ} \mathrm{C}$, TMS): $\delta_{\mathrm{H}}=0.03-0.09$ (m, $2 \mathrm{H}, 2 \times \mathrm{CH} \mathrm{H}$ of cyclopropane), $0.36-0.44 \quad(\mathrm{~m}, 2 \mathrm{H}, 2 \times \mathrm{CH} \mathrm{H}$ of cyclopropane), $0.61-0.76 \quad(\mathrm{~m}, \quad 1 \mathrm{H}, \quad \mathrm{CH}$ of cyclopropane $), \quad 1.78\left(\mathrm{~d},{ }^{3} \mathrm{~J}(\mathrm{H}, \mathrm{H})=6.5 \mathrm{~Hz}\right.$, $\left.2 \mathrm{H}, \mathrm{CCH} \mathrm{H}_{2} \mathrm{CH}\right), 2.67-2.72\left(\mathrm{~m}, 2 \mathrm{H},(\mathrm{CH}=\mathrm{CH})_{2} \mathrm{CH}_{2}\right)$, $5.75\left(\right.$ app dt, ${ }^{3} J(\mathrm{H}, \mathrm{H})=10.4 \mathrm{~Hz},{ }^{3} J(\mathrm{H}, \mathrm{H})=1.8 \mathrm{~Hz}$, $\left.2 \mathrm{H},(\mathrm{CH}=\mathrm{CH})_{2} \mathrm{C}(\mathrm{Ph})\right), 5.84\left(\right.$ app $\mathrm{dm},{ }^{3} J(\mathrm{H}, \mathrm{H})=$ $\left.10.4 \mathrm{~Hz}, 2 \mathrm{H},(\mathrm{CH}=\mathrm{CH})_{2} \mathrm{C}(\mathrm{Ph})\right), 7.12-7.21(\mathrm{~m}, 1 \mathrm{H}$, $\mathrm{Ph}), 7.26-7.40(\mathrm{~m}, 4 \mathrm{H}, \mathrm{Ph}) ;{ }^{13} \mathrm{C}$ NMR $(75 \mathrm{MHz}$, $\left.\mathrm{CDCl}_{3}, 25^{\circ} \mathrm{C}, \mathrm{TMS}\right): \delta_{\mathrm{C}}=5.22\left(2 \mathrm{C}, 2 \times \mathrm{CH}_{2}\right.$ of cyclopropane), 7.26 ( $\mathrm{CH}$ of cyclopropane), 26.25 $\left(\mathrm{CCH}_{2} \mathrm{CH}\right), \quad 44.94 \quad\left((\mathrm{CH}=\mathrm{CH})_{2} \mathrm{C}(\mathrm{Ph})\right), \quad 45.90$ $\left((\mathrm{CH}=\mathrm{CH})_{2} \mathrm{CH}_{2}\right), \quad 123.09 \quad\left(2 \mathrm{C}, \quad(\mathrm{CH}=\mathrm{CH})_{2} \mathrm{CH}_{2}\right)$, $125.91\left(\mathrm{CH}_{\mathrm{ar}}\right), 126.79\left(2 \mathrm{C}, \mathrm{CH}_{\mathrm{ar}}\right), 128.37(2 \mathrm{C}$, $\left.\left.\mathrm{CH}_{\mathrm{ar}}\right), 133.35(2 \mathrm{C}, \mathrm{CH}=\mathrm{CH})_{2} \mathrm{C}(\mathrm{Ph})\right), 148.34\left(\mathrm{C}_{\mathrm{Ph}}\right)$; MS (70eV): $m / z(\%): 212(0.03)\left[M^{+}+2\right], 211(0.33)$ $\left[M^{+}+1\right], 210(1.93)\left[M^{\square+}\right], 156(13), 155(100), 154$ (31), 153 (12); HRMS: (EI) $\mathrm{m} / z$ calcd for $\mathrm{C}_{16} \mathrm{H}_{18}$ 210.1408 , found 210.1395 .

(1-(3-Butenyl)cyclohexa-2,5-dienyl)benzene (4a'):<smiles>C=CCCC1(c2ccccc2)C=CCC=C1</smiles>
$R_{\mathrm{f}}=0.61$ (hexane); IR (film): $v$ $\left(\mathrm{cm}^{-1}\right)=3028,2924,2847,2809$, $1634,1602,1487,1441,908$, 744, 700; ${ }^{1} \mathrm{H}$ NMR $(300 \mathrm{MHz}$, $\left.\mathrm{CDCl}_{3}, 25^{\circ} \mathrm{C}, \mathrm{TMS}\right): \delta_{\mathrm{H}} 1.82-$ $1.94\left(\mathrm{~m}, 2 \mathrm{H}, \quad(\mathrm{Ph}) \mathrm{CCH}_{2} \mathrm{CH}_{2}\right)$, $1.99-2.11 \quad(\mathrm{~m}, \quad 2 \mathrm{H}$, $\left.\mathrm{CH}_{2} \mathrm{CH}_{2} \mathrm{CH}=\mathrm{CH}_{2}\right), \quad 2.63-2.73 \quad(\mathrm{~m}, \quad 2 \mathrm{H}$, $\left.(\mathrm{CH}=\mathrm{CH})_{2} \mathrm{CH}_{2}\right), 4.94\left(\operatorname{app~dm},{ }^{3} J(\mathrm{H}, \mathrm{H})=10.2 \mathrm{~Hz}\right.$, $1 \mathrm{H}, \mathrm{CH}=\mathrm{CH} H), 5.02\left(\right.$ app dm, ${ }^{3} J(\mathrm{H}, \mathrm{H})=17.1 \mathrm{~Hz}$, $1 \mathrm{H}, \mathrm{CH}=\mathrm{C} H \mathrm{H}), 5.61\left(\mathrm{app} \mathrm{dt},{ }^{3} J(\mathrm{H}, \mathrm{H})=10.5 \mathrm{~Hz}\right.$, $\left.{ }^{4} J(\mathrm{H}, \mathrm{H})=2.0 \mathrm{~Hz}, 2 \mathrm{H},(\mathrm{CH}=\mathrm{CH})_{2} \mathrm{C}(\mathrm{Ph})\right), 5.80-5.96$ (m, 3H, $\left.(\mathrm{CH}=\mathrm{CH})_{2} \mathrm{CH}_{2}, \mathrm{CH}=\mathrm{CH}_{2}\right), 7.14-7.21(\mathrm{~m}$, $1 \mathrm{H}, \mathrm{Ph}), 7.27-7.40(\mathrm{~m}, 4 \mathrm{H}, \mathrm{Ph}) ;{ }^{13} \mathrm{C}$ NMR $(75 \mathrm{MHz}$, $\left.\mathrm{CDCl}_{3}, 25^{\circ} \mathrm{C}, \mathrm{TMS}\right): \delta_{\mathrm{C}}=26.26\left((\mathrm{CH}=\mathrm{CH})_{2} \mathrm{CH}_{2}\right)$, $29.78\left(\mathrm{CH}_{2} \mathrm{CH}_{2} \mathrm{CH}=\mathrm{CH}_{2}\right), 39.29\left((\mathrm{Ph}) \mathrm{CCH}_{2} \mathrm{CH}_{2}\right)$, $44.04 \quad\left((\mathrm{CH}=\mathrm{CH})_{2} C(\mathrm{Ph})\right), \quad 114.18 \quad\left(\mathrm{CH}_{2}=\mathrm{CH}\right)$, $123.87\left(2 \mathrm{C},(\mathrm{CH}=\mathrm{CH})_{2} \mathrm{CH}_{2}\right), 126.05\left(\mathrm{CH}_{\mathrm{Ph}}\right), 126.77$ $\left(2 \mathrm{C}, 2 \times \mathrm{CH}_{\mathrm{Ph}}\right), 128.42\left(2 \mathrm{C}, 2 \times \mathrm{CH}_{\mathrm{Ph}}\right), 132.55(2 \mathrm{C}$, $\left.(\mathrm{CH}=\mathrm{CH})_{2} \mathrm{C}(\mathrm{Ph})\right), 139.44\left(\mathrm{CH}=\mathrm{CH}_{2}\right), 148.26\left(\mathrm{C}_{\mathrm{Ph}}\right)$; MS (70eV): $m / z(\%): 211(0.08)\left[M^{+}+1\right], 210(0.36)$
$\left[M^{\square+}\right], 156$ (13), 155 (100), 154 (15), 153 (12); HRMS: (EI) $\mathrm{m} / z$ calcd for $\mathrm{C}_{16} \mathrm{H}_{18} 210.1408$, found 210.1401.

(1-Cyclobutyl)cyclohexa-2,5-dienyl)benzene (4a'"):

$$
R_{\mathrm{f}}=0.46 \text { (hexane); IR (film): } v\left(\mathrm{~cm}^{-}\right.
$$<smiles>C1=CCC(c2ccccc2)(C2CCC2)C=C1</smiles>

$\left.{ }^{1}\right)=3021,2964,2928,2850,2814$, 1484, 1448, 1203, 1130, 938, 759, 698, 681; ${ }^{1} \mathrm{H}$ NMR $(300 \mathrm{MHz}$, $\left.\mathrm{CDCl}_{3}, 25^{\circ} \mathrm{C}, \mathrm{TMS}\right): \delta_{\mathrm{H}} \quad 1.62-1.99$ $\left(\mathrm{m}, 6 \mathrm{H}, 3 \times \mathrm{CH}_{2}\right.$ of cyclobutane), 1.99-2.11 (m, $2 \mathrm{H}$, $\left.\mathrm{CH}_{2} \mathrm{CH}_{2} \mathrm{CH}=\mathrm{CH}_{2}\right), \quad 2.66-2.76 \quad(\mathrm{~m}$, $\left.2 \mathrm{H},(\mathrm{CH}=\mathrm{CH})_{2} \mathrm{CH}_{2}\right), 2.85-3.02(\mathrm{~m}, 1 \mathrm{H}, \mathrm{CH}$ of cyclobutane), $5.65\left(\mathrm{app} \mathrm{dt},{ }^{3} J(\mathrm{H}, \mathrm{H})=10.4 \mathrm{~Hz}\right.$, $\left.{ }^{4} J(\mathrm{H}, \mathrm{H})=2.0 \mathrm{~Hz}, 2 \mathrm{H},(\mathrm{CH}=\mathrm{CH})_{2} \mathrm{C}(\mathrm{Ph})\right), 5.90(\mathrm{app}$ $\mathrm{dt},{ }^{3} J(\mathrm{H}, \mathrm{H})=10.5 \mathrm{~Hz},{ }^{4} J(\mathrm{H}, \mathrm{H})=3.3 \mathrm{~Hz}, 2 \mathrm{H}$, $\left.(\mathrm{CH}=\mathrm{CH})_{2} \mathrm{CH}_{2}\right), 7.10-7.21\left(\mathrm{~m}, 1 \mathrm{H}, \mathrm{CH}_{\mathrm{Ph}}\right), 7.26-$ $7.33\left(\mathrm{~m}, 4 \mathrm{H}, 4 \times \mathrm{CH}_{\mathrm{Ph}}\right) ;{ }^{13} \mathrm{C}$ NMR $\left(75 \mathrm{MHz}, \mathrm{CDCl}_{3}\right.$, $\left.25^{\circ} \mathrm{C}, \mathrm{TMS}\right): \delta_{\mathrm{C}}=17.67,23.69\left(2 \mathrm{C}, 2 \times \mathrm{CH}_{2}\right.$ of cyclobutane $), 26.61,43.15\left((\mathrm{CH}=\mathrm{CH})_{2} \mathrm{CH}_{2}\right), 46.25$ $\left((\mathrm{CH}=\mathrm{CH})_{2} \mathrm{C}(\mathrm{Ph})\right), 124.06 \quad\left(2 \mathrm{C}, \quad(\mathrm{CH}=\mathrm{CH})_{2} \mathrm{CH}_{2}\right)$, $125.92\left(\mathrm{CH}_{\mathrm{Ph}}\right), 127.30\left(2 \mathrm{C}, 2 \times \mathrm{CH}_{\mathrm{Ph}}\right), 128.29(2 \mathrm{C}$, $\left.2 \times \mathrm{CH}_{\mathrm{Ph}}\right), 130.98\left(2 \mathrm{C}, 2 \times(\mathrm{CH}=\mathrm{CH})_{2} \mathrm{C}(\mathrm{Ph})\right), 147.49$ $\left(\mathrm{C}_{\mathrm{Ph}}\right) ; \mathrm{MS}(70 \mathrm{eV}): m / z(\%): 211(0.08)\left[M^{+}+1\right], 210$ (0.54) $\left[M^{\square+}\right], 156$ (13), 155 (100), 154 (27), 153 (14), 152 (10); HRMS: (EI) $\mathrm{m} / z$ calcd for $\mathrm{C}_{16} \mathrm{H}_{18}$ 210.1408 , found 210.1391 .

\section{SUPPORTING INFORMATION}

General, Additional information on the synthesis of 1a and ${ }^{1} \mathrm{H}$ and ${ }^{13} \mathrm{C}$ NMR spectra of 1a, 2a, 3a, 3a', 3a', $\mathbf{4 a}, \mathbf{4 a}$ ' and $\mathbf{4 a}$ ', are included in supplementary material.

\section{Acknowledgements}

This work was generously supported by the Spanish Ministerio de Educación y Ciencia (CTQ201124165) and the Universidad de Alicante. IB thanks the Instituto de Síntesis Orgánica for financial support.

\section{REFERENCES AND NOTES}

\footnotetext{
${ }^{1}$ The involvement of these dianions has been proposed only in a limited number of studies: $\mathrm{Li}_{2} \mathrm{C}_{10} \mathrm{H}_{8}$ : a) J. Smid J. Am. Chem. Soc. 1965, 87, 655-656. b) R. Benken, H. Günther, Helv. Chim. Acta 1988, 71, 694-702. c) M. Yus, R. P. Herrera, A. Guijarro, Chem. Eur. J. 2002, 8, 2574-2584. $\mathrm{Li}_{2} \mathrm{C}_{12} \mathrm{H}_{10}$ : d) W. Huber, A May, K. Müllen, Chem. Ber. 1981, 114, 1318-1336. e) J. J. Eisch J. Org. Chem. 1963, 28, 707-710.

${ }^{2}$ C. Melero, R. P. Herrera, A. Guijarro, M. Yus Chem. Eur. J. 2007, 13, 10096-100107.

${ }^{3}$ Melero, C.; Guijarro, A.; Yus, M. Dalton Trans. 2009, 12861289.

${ }^{4}$ a) S. Irle, H. Lischka J. Chem. Phys. 1995, 103, 1508-1522. b) M. de la Viuda, M. Yus, A. Guijarro, J. Phys. Chem. B, 2011, 115, 14610-14616.
} 
${ }^{5}$ (a) The pair $\mathrm{Li}_{(\mathrm{s})} / \mathrm{Li}^{+}{ }_{(\mathrm{H} 2 \mathrm{O})}$ is the most negative among alkali metals, with a standard potential $E_{(\mathrm{Li} / \mathrm{Li}+)}^{\mathrm{o}}=-3.04 \mathrm{~V}$, in water relative to SHE: CRC Handbook of Chemistry and Physics, 85th ed. (Dr. Lide, Ed.), CRC Press, Boca Raton, FL., 2004, pp 8-33. (b) In THF, a reported half-peak potential for the pair $\mathrm{Li}_{(\mathrm{s})} / \mathrm{Li}^{+}{ }_{(\mathrm{THF})}$ is $E_{1 / 2}\left(\mathrm{Li} / \mathrm{Li}^{+}\right)=-3.07 \mathrm{~V}$ vs. $\mathrm{Ag} / \mathrm{AgCl}$ : Mortensen, J.; Heinze, J. Tetrahedron Lett. 1985, 26, 415-418. (c) The formal $\mathrm{Li}_{(\mathrm{s})} / \mathrm{Li}^{+}{ }_{(\mathrm{THF})}$ potencial was measured recently, $E_{0}{ }^{\mathrm{f}}=-3.48 \mathrm{~V} \mathrm{vs}$. Fc/Fc $^{+} \mathrm{PF}^{6-}$ : Paddon, C. A.; Ward Jones, S. E.; Bhatti, F. L., Donohoe, T. J.; Compton, R. G. J. Phys. Org. Chem. 2007, 20, 677-684.

${ }^{6}$ Among polycyclic aromatic hydrocarbons, naphthalene, holds the highest -yet to be measured-second reduction potential $E_{2}^{\circ}\left(\mathrm{C}_{10} \mathrm{H}_{8}, E^{\circ}{ }_{1}=-2.53 \mathrm{~V} ; E_{2}^{\circ}=\right.$ beyond the experimental limit). Biphenyl on the other hand, has the highest first reduction potential $E_{1}^{\circ}$, giving rise to the radical anion, and the second higher $E_{2}^{\circ}$, affording the dianion $\left(\mathrm{C}_{12} \mathrm{H}_{10}, E^{\mathrm{o}}{ }_{1}=-2.68 \mathrm{~V}, E_{2}^{\circ}=-\right.$ $3.18 \mathrm{~V})$. All measured in $\mathrm{Me}_{2} \mathrm{NH}$ vs. Ag/AgCl: Meerholz, K.; Heinze, J. J. Am. Chem. Soc. 1989, 111, 2325-2326.

${ }^{7}$ Taking $E_{(\mathrm{L} / \mathrm{Li}+)}^{\circ} \approx-3.08 \mathrm{~V}$ vs. $\mathrm{Ag} / \mathrm{AgCl}$ as a reasonble value in THF and comparing it to the second reduction wave of biphenyl, $E_{2(\mathrm{Bp}-2 / \mathrm{Bp}-1)}^{\circ}=-3.18 \mathrm{~V} \mathrm{vs}$. $\mathrm{Ag} / \mathrm{AgCl}$, it turns out that the lithium double reduction of biphenyl is slightly endergonic under standard conditions $\left(\Delta G^{\circ}=-n F E^{\circ}\right)$. The situation is even more unfavorable for naphthalene. Although this is only approximate since electrochemical data comes from different sources under different conditions (e.g. solvent), it is still indicative of the reducing strength of the dianions considered in this work.

${ }^{8}$ a) C. Melero, A. Guijarro, M. Yus, Tetrahedron Lett. 2006, 47, 6267-6271. b) C. Melero, A. Guijarro, V. Baumann, A. J. PerezJimenez, M. Yus, Eur. J. Org. Chem. 2007, 5514-5526.

${ }^{9}$ R. P. Herrera, A. Guijarro, M. Yus, Tetrahedron Lett. 2003, 44 1309-1312.

${ }^{10}$ (a) J. F. Garst, F. E. Barton II, Tetrahedron Lett. 1969, 7, 587-590. (b) J. F. Garst, F. E. Barton II, J. Am. Chem. Soc. 1974, 96, 523-529.

1 Percy, J. M. In Science of Synthesis; Percy, J. M., Ed.; Thieme: Stuttgart, 2006; Vol. 34, pp 267-268.

12 J. R. During, Z. Yu, C. Zheng, G. Guirguis, J. Phys. Chem. A 2004, 108, 5353-5364.

${ }^{13}$ B. M. Kraft, R. J. Lachicotte, and W. D. Jones, J. Am. Chem. Soc. 2001, 123, 10973-10979.

${ }^{14}$ (a) L. Mattew, J. Warkentin, J. Am. Chem. Soc. 1986, 108, 7981-7984

${ }^{15}$ D. P. Cox, J. Terpinski, W. Lawrynowicz, W. J. Org. Chem. 1984, 49, 3216-3219.

${ }^{16} \mathrm{Cp}^{*}{ }_{2} \mathrm{ZrH}_{2}$ was introduced in this paper as a reagent of hydrodefluorination. Its reactivity against monofluorinated aliphatic C-F bonds was described to decrease in the order $1^{\circ}>$ $2^{\circ}>3$. In our hands, the organic layer consisted of $74 \%$ of cyclopropylmethyl fluoride, $24 \%$ of cyclobutyl fluoride and $2 \%$ of 3-butenyl fluoride. The purification step was apparently against the reported order of reactivity given by the authors, and was not carried out.

17 Z. Mo, Q. Zhang, L. Deng Organometallics 2012, 31, 65186521.

${ }^{18}$ D. D. Roberts, J. Org. Chem., Vol. 1970, 35, 4059-4062.

19 S. L. Bogen, S. Ruan, R. Liu, S. Agrawal, J. Pichardo, A. Prongay, B. Baroudy, A. K. Saksena, V. Girijavallabhan, F. G. Njoroge, Bioorg. Med. Chem. Lett. 2006, 16, 1621-1627.

${ }^{20}$ D. D. Roberts, J. Org. Chem. 1965, 30, 23-28.

${ }^{21}$ L. Mathew, J. Warkentin, J. Am. Chem. Soc. 1986, 108, 7981-7984.

${ }^{22}$ (a) J. K. Kochi, J. W. Powers, J. Am. Chem. Soc. 1970, 92, 137-146. (b) C. L. Jenkins, J. K. Kochi, J. Org. Chem. 1971, 36, 3103-3111.

${ }^{23}$ In this approach, the anionic rearrangement $\left(k_{r}^{\prime}\right)$ in Scheme 1 have been purposely set to zero. For the hex-5-enyllithium, the anionic cyclization $k_{r}^{\prime}$ is known to be ca. $10^{8}$ times slower than the corresponding radical cyclization: W. F. Bayley, J. J. Patricia, V. C. DelGobbo, R. M. Jarret, P. J. Okarma, J. Org. Chem. 1985, 50, 2000-2003. For the cyclopropylmethyllithium $k_{\mathrm{r}}$ has not been determined, to our best knowledge.
${ }^{24}$ Notice that this splitting is mathematically exact given that $[R A H] /\left[R^{\prime} A H\right]=[R H] /\left[R^{\prime} H\right]$, which is the case in here since both equal to $\left.\left[R^{\cdot} \cdot\right] / R^{\prime} \cdot\right]$. The chemical meaning of this is more subtle and entails that both $k_{\text {red }}$ and $k_{\text {coupl }}$ are the same for R. and R'. Dealing with only one set of constants $\left(k_{\text {red }}\right.$ and $\left.k_{\text {coupl }}\right)$ is an acceptable approximation implicit in Scheme 3 that simplifies much the model. In any case, the toughest test for the model comes at the limit of diffusion controlled reactions of R. and R'. with $\mathrm{Li}_{x} \mathrm{~A}$. This limiting case is also considered and explained later in this work.

${ }^{25}$ The corresponding coupling products (RAH + R'AH) were isolated and characterized only recently. Full characterization of these compounds can be found in ref. 2.

${ }^{26}$ We have also observed mixtures of both rearranged and nonrearranged products in the reaction of hex-5-enyl fluoride with LiNp: see ref. 9.

${ }^{27}$ Data from: a) CRC Handbook of Chemistry and Physics, Internet Version 2007, 87th Edition, Taylor and Francis, Boca Raton, FL, 2007, pp 15-21 and 15-16.

${ }^{28}$ D. J. Carlsson, K. U. Ingold, J. Am. Chem. Soc. 1968, 90, 7047-55.

${ }^{29}$ a) C. L. Jenkins, J. K. Kochi, J. Org. Chem. 1971, 36, 31033111. b) B. Maillard, D. Forrest, K. U. Ingold, J. Am. Chem. Soc. 1976, 98, 7024-7026.

${ }^{30}$ This rearrangement is reversible, but the equilibrium heavily favors the 3-butenyl radical by a factor $>10^{4}$ at $25^{\circ} \mathrm{C}$, so the reverse reaction can be ignored for our purposes: A. Effio, D. Griller, K. U. Ingold, A. L. J. Beckwith, K. J. Serelis, J. Am. Chem. Soc. 1980, 102, 1734-1736.

${ }^{31}$ H. Hazimeh, J.-M. Mattalia, C. Marchi-Delapierre, R. Barone, N. S. Nudelman, M. Chanon J. Phys. Org. Chem. 2005, 18, 1145-1160.

${ }^{32}$ However, if the arene bears electron withdrawing groups capable of further dianion stabilization (such as -CN), the carbanion is softened and alkylation becomes a main reaction outcome with interesting synthetic applicationsT. A. Vaganova, E. V. Panteleeva, V. D. Shteingarts, Russ. Chem. Bull. 2008, 57, 768-779.

${ }^{33}$ 4-Fluoro-1-butene (3a') was prepared by reaction of 3butenyl tosylate with $\mathrm{KF}$ in triethyleneglycol following the procedure described in: J. San Filippo Jr., L. J. Romano J. Org. Chem., 1975, 40, 1514-1515. Cyclobutyl fluoride (3a") was prepared by reaction of cyclobutanol with DAST: T. B. Patrick, L. Zhang, Q. Li, J. Fluorine Chem. 2000, 102, 11-15. 


\title{
Supporting Information
}

\section{On the Reactivity of Naphthalene and Biphenyl Dianions: Tying up Loose Ends concerning an $\mathrm{S}_{\mathrm{N}} 2$-ET Dichotomy in Alkylation Reactions}

\author{
Inmaculada Blasco, Henoc Pérez and Albert Guijarro* \\ Departamento de Química Orgánica and Instituto de Síntesis Orgánica. Universidad de Alicante. Campus de Sant \\ Vicent del Raspeig, Apdo. 99, E-03080, Alicante, Spain. Fax: (+34) 965-90-35-49. E-mail: aguijarro@ua.es.
}

Table of Contents

1. General

2. Additional information on the synthesis of cyclopropylmethyl fluoride (1a). S2

3. ${ }^{1} \mathrm{H}$ and ${ }^{13} \mathrm{C}$ NMR spectra. 


\section{General}

All moisture sensitive reactions were carried out under argon atmosphere. THF and THP were dried and distilled over $\mathrm{Na} / \mathrm{K}$ alloy right before use. Commercially available naphthalene and biphenyl, as well as other reagents were used without further purification (Acros, Aldrich, Fluka). Dichloromethane was dried out and distilled from phosphorous pentoxide and triethylamine from potassium hydroxide. $p$-Toluene sufonyl chloride was recrystallized from benzene. Lithium powder was prepared from lithium granules (Aldrich 99\%, high sodium content) using an impact grinding mill. All glassware was dried in an oven at $100^{\circ} \mathrm{C}$ and cooled to room temperature under Ar before use. Gas chromatography analyses (GLC) were carried out with a Hewlett Packard HP-5890 instrument equipped with a flame ionization detector and a $30 \mathrm{~m}$ HP-5 capillary column $(0.32 \mathrm{~mm}$ diam, $0.25 \mu \mathrm{m}$ film thickness), using nitrogen as carrier gas (12 psi). Column chromatography was performed with Merck silica gel $60(0.040-0.063 \mu \mathrm{m}, 240-400 \mathrm{mesh})$. Thin-layer chromatography (TLC) was performed on precoated silica gel plates (Merck 60, F254, $0.25 \mathrm{~mm}$ ). Detection was done by $\mathrm{UV}_{254}$ light; $R_{\mathrm{f}}$ values are given under these conditions. NMR spectra were recorded on a Bruker Avance 300 and Bruker Avance 400 (300 and $400 \mathrm{MHz}$ for ${ }^{1} \mathrm{H} \mathrm{NMR}$, and 75 and $100 \mathrm{MHz}$ for ${ }^{13} \mathrm{C}$ $\mathrm{NMR}$, respectively) using $\mathrm{CDCl}_{3}$ as solvent and TMS as internal standard. Mass spectra (EI) were obtained at $70 \mathrm{eV}$ on a Shimadzu QP-5000 and Agilent 5973 spectrometers, fragment ions in $\mathrm{m} / \mathrm{z}$ with relative intensities (\%) in parenthesis. HRMS analyses were carried out on a Finnigan MAT95S spectrometer. Infrared (FT-IR) spectra were obtained on a Nicolet Impact 400D spectrophotometer using $\mathrm{NaCl}$ plates.

\section{Additional information on the synthesis of cyclopropylmethyl fluoride (1a).}

As mentioned in the main text, the synthesis of cyclopropylmethyl fluoride by nuclephilic fluorination of an appropriate cyclopropylmethyl derivative initially faced us with an additional problem: the easy cationic isomerisation of this structure. It occurs via the cyclopropylmethyl carbocation triad, which includes the cyclobutyl and 3-butenyl cations (Scheme S1). A cyclopropyl group exerts a strong stabilizing effect on a carbocation center in $\alpha$-position to the ring. The nonclassic, rather stable nature of the cyclopropylmethyl cation and ease of isomerisation was explained on the basis of ab initio calculations. Two non-classic minima structures are found, both very close in energy (Scheme S2). ${ }^{1}$

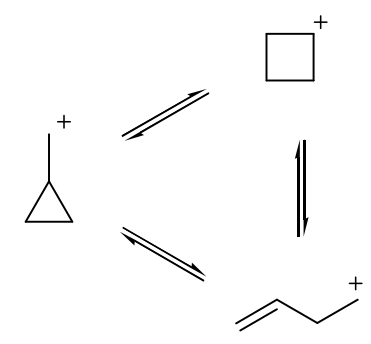

Scheme S1. Cyclopropylmethyl cation triad.

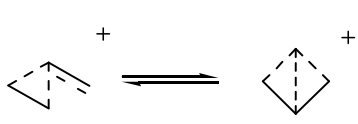

${ }^{1}$ G. A. Olah, G. K. S. Prakash, G. Rasul, J. Am. Chem. Soc. 2008, 130, 9168-9172. 
Scheme S2. Calculated gas phase more stable non-classic cations of $\mathrm{C}_{4} \mathrm{H}_{7}^{+}$: Cyclopropylmethyl cation in bisected conformation (left) and its isomeric bicyclobutonium cation (right). From reference 1 .

Cyclopropylmethyl tosylate (4a) is the starting material needed to obtain $\mathbf{3 a} .^{2}$ It has been described as a liquid too unstable to purify by distillation, and it is often overlooked in the synthetic literature that $4 \mathbf{a}$ is a rather unstable compound that should be carefully manipulated to avoid the above mentioned skeletal rearrangements as well as further decomposition. As a guide, we have included the solvolysis half-lives of $\mathbf{4 a}$ in several solvents at $25^{\circ} \mathrm{C}$, calculated from the kinetic data collected by Roberts (Table S1). ${ }^{3}$ These half-lives correspond to the titration of $p$-toluenesulfonic acid liberated in the media after solvolysis. The actual isomerisation half-lives are therefore expected to be even shorter due to the presence of internal-return isomerisation of tosylates (according to Scheme S1), a fact that has been corroborated by us. Upon standing for long periods, cyclobutyl tosylate becomes a major component of the isomerising mixture of neat $4 \mathbf{a}$.

Table S1. Activation parameters of solvolysis of cyclopropylmethyl tosilate $\mathbf{4 a}$ in different solvents and solvolysis half-lives at $25^{\circ} \mathrm{C}$ calculated from ref. 3 .

\begin{tabular}{lllll}
\hline solvent & $T\left({ }^{\circ} \mathrm{C}\right)$ & $\Delta H^{\ddagger}(\mathrm{kcal} / \mathrm{mol})$ & $\Delta S^{\ddagger}(\mathrm{e} . \mathrm{u})$. & $t_{\frac{1}{2}}$ at $25^{\circ} \mathrm{C}$ \\
\hline sulfolane & $35-60$ & $15.8 \pm 0.60$ & $-30.0 \pm 2.0$ & $42.6 \mathrm{~h}$ \\
methanol & $10-30$ & $20.1 \pm 0.34$ & $-7.3 \pm 1.0$ & $40 \mathrm{~min}$ \\
dimethylsulfoxide & $20-40$ & $16.9 \pm 0.20$ & $-20.0 \pm 1.0$ & $106 \mathrm{~min}$ \\
isopropanol & $25-50$ & $16.3 \pm 0.40$ & $-24.2 \pm 1.5$ & $5.3 \mathrm{~h}$ \\
$90 \%$ acetone & $25-50$ & $17.0 \pm 0.60$ & $-21.5 \pm 2.0$ & $4.5 \mathrm{~h}$ \\
\hline
\end{tabular}

\section{3. ${ }^{1} \mathrm{H}$ and ${ }^{13} \mathrm{C}$ NMR spectra.}

\footnotetext{
${ }^{2}$ We tried at this point to seek for a compromise between an improved stability of different cyclopropylmethyl sulfonates while preserving their reactivity towards the fluoride anion at a suitable temperature. Alternative sulfonates were tested in addition to 4- $\mathrm{CH}_{3}-\mathrm{C}_{6} \mathrm{H}_{4} \mathrm{SO}_{3}^{-}$, including 4-Cl- $\mathrm{C}_{6} \mathrm{H}_{4} \mathrm{SO}_{3}^{-}$, 4- $\mathrm{Br}_{-} \mathrm{C}_{6} \mathrm{H}_{4} \mathrm{SO}_{3}^{-}$, 4- $-\mathrm{I}_{6} \mathrm{H}_{4} \mathrm{SO}_{3}^{-}$, 4- $\mathrm{CF}_{3}-\mathrm{C}_{6} \mathrm{H}_{4} \mathrm{SO}_{3}{ }^{-}$(unstable at $0^{\circ} \mathrm{C}$ ), 4- $\mathrm{NO}_{2}-\mathrm{C}_{6} \mathrm{H}_{4} \mathrm{SO}_{3}{ }^{-}$(highly unstable, decomposes), 2,4-di- $\mathrm{NO}_{2}-\mathrm{C}_{6} \mathrm{H}_{3} \mathrm{SO}_{3}{ }^{-}$(highly unstable, decomposes), penta- $\mathrm{CH}_{3}{ }^{-}$ $\mathrm{C}_{6}-\mathrm{SO}_{3}^{-}, \mathrm{CH}_{3} \mathrm{SO}_{3}^{-}$(unstable at $0^{\circ} \mathrm{C}$ ). Among the stable ones at $0^{\circ} \mathrm{C}$ (the reaction proceeds in general very slowly at lower temperatures), the best performing groups in the following fluorination step turned out to be the tosylate and the 4chlorobencenesulfonate, both with similar results.
}

${ }^{3}$ D. D. Roberts, J. Org. Chem. 1965, 30, 23-28. 


1
2
3
4
5
6
7
8
9
10
11
12
13
14
15
16
17
18
19
20
21
22
23
24
25
26
27
28
29
30
31
32
33
34
35
36
37
38
39
40
41
42
43
44
45
46
47
48
49
50
51
52
53
54
55
56
57
59
60
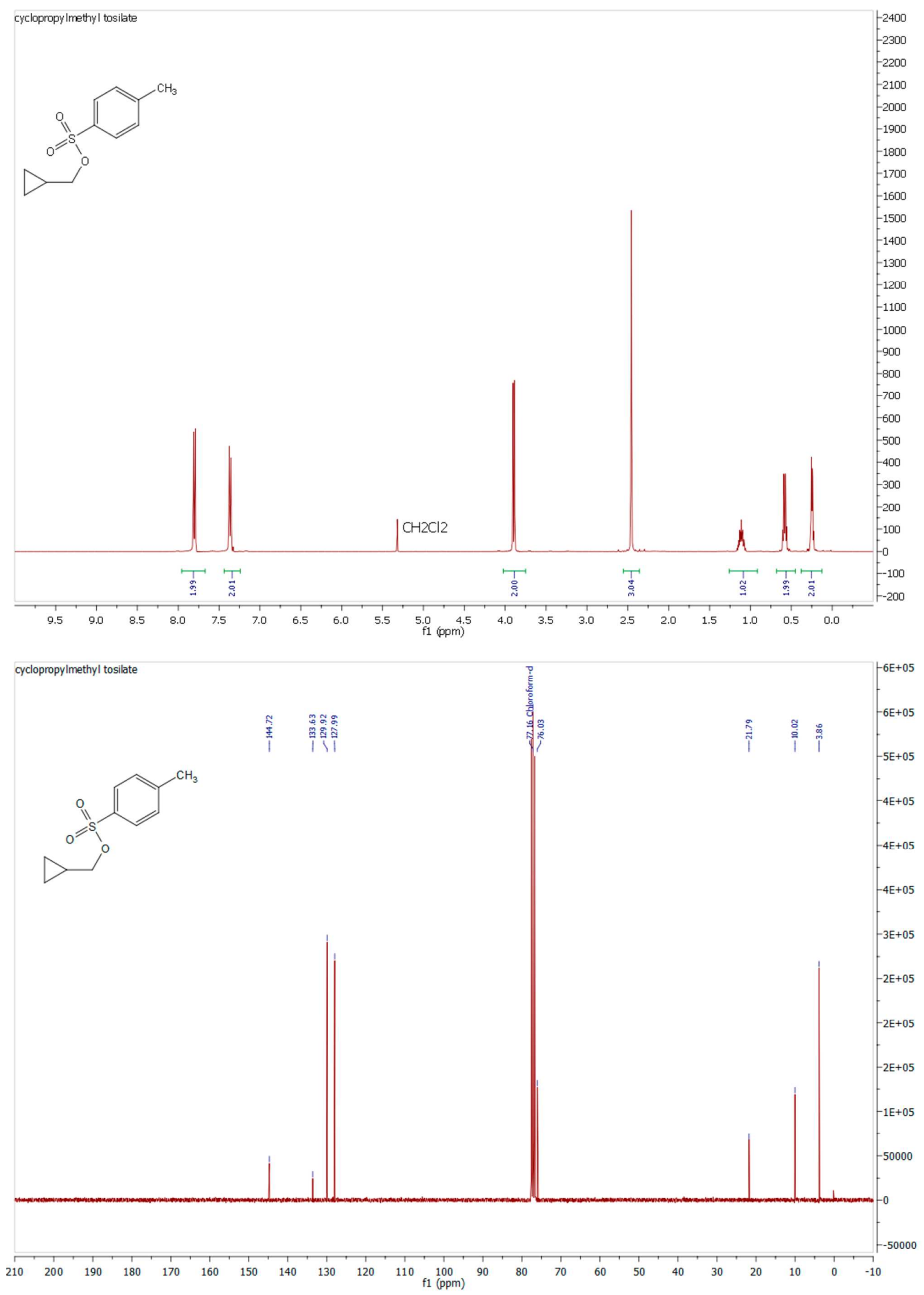

http://mc.manuscriptcentral.com/poc 

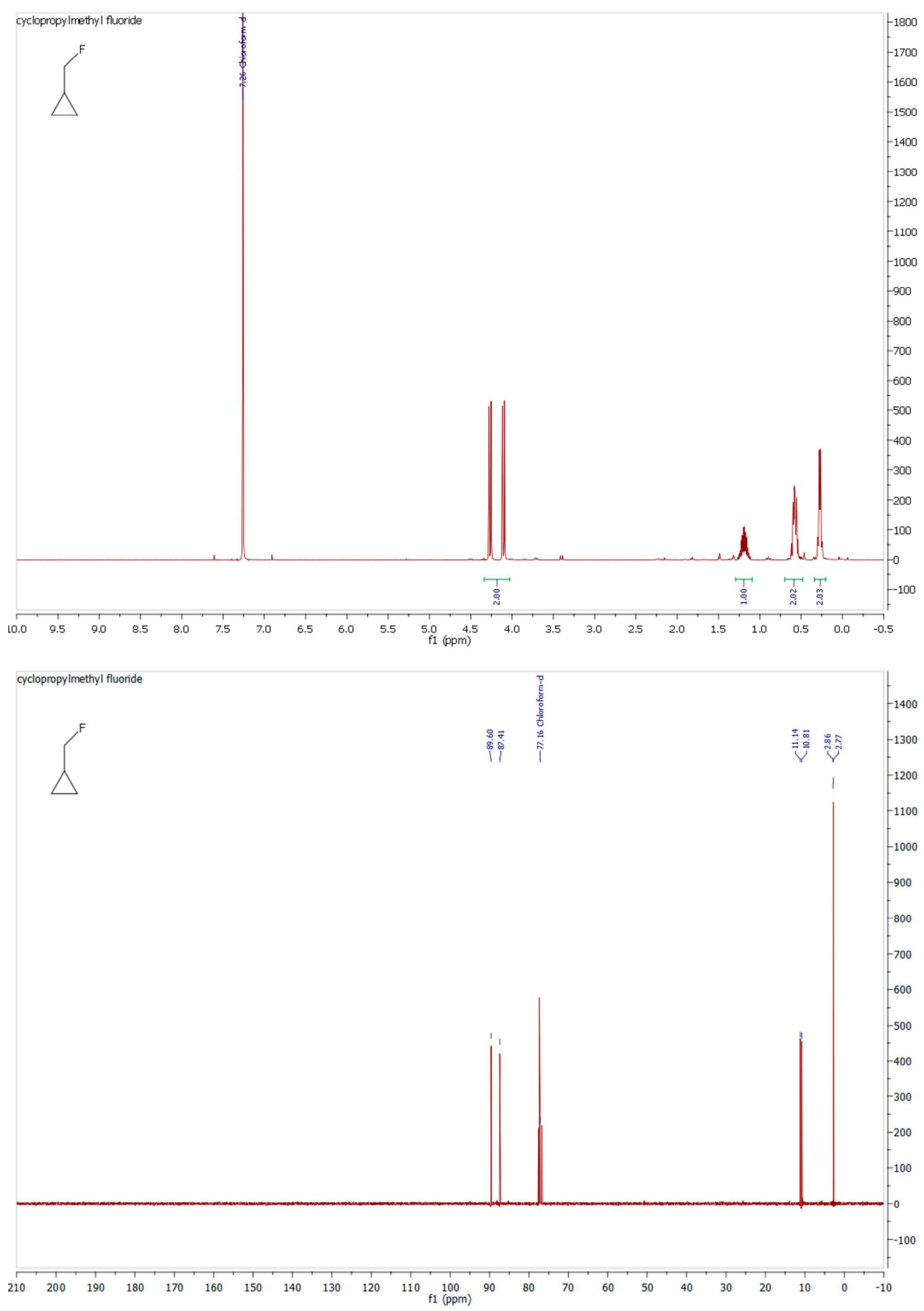
Journal of Physical Organic Chemistry

Page 18 of 23

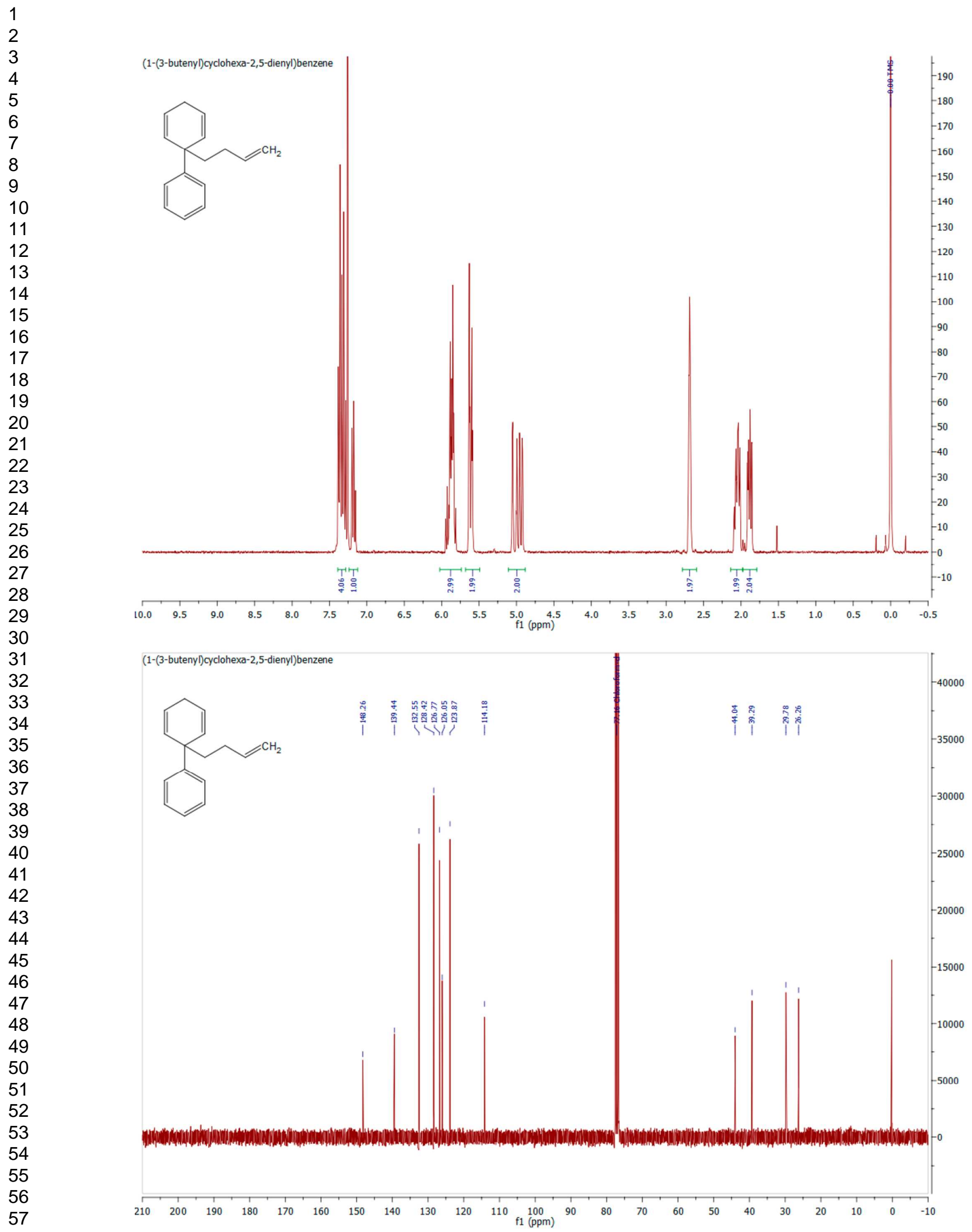

http://mc.manuscriptcentral.com/poc

ST 


1
2
3
4
5
6
7
8
9
10
11
12
13
14
15
16
17
18
19
20
21
22
23
24
25
26
27
28
29
30
31
32
33
34
35
36
37
38
39
40
41
42
43
44
45
46
47
48
49
50
51
52
53
54
55
56
57
59
60
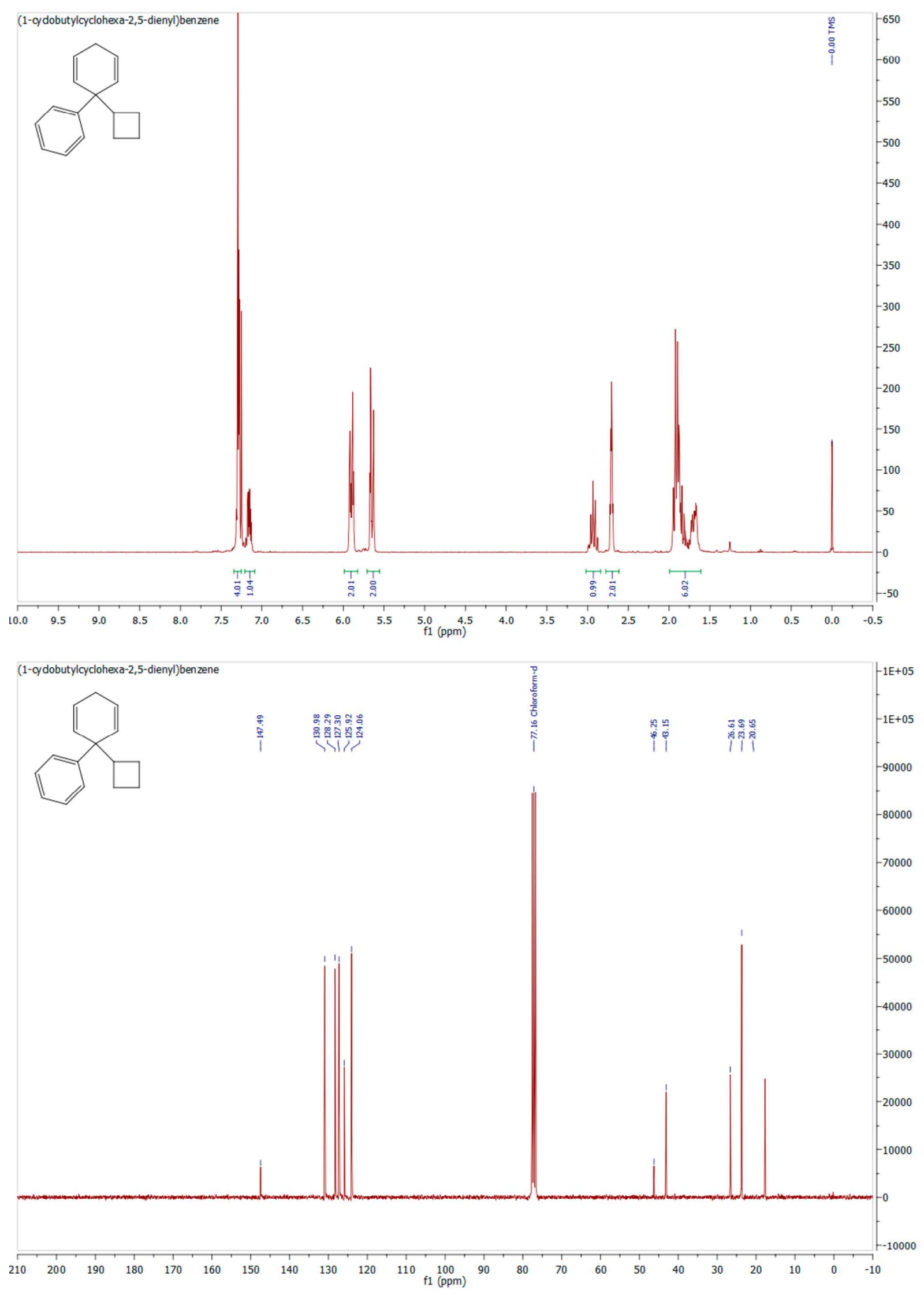

http://mc.manuscriptcentral.com/poc 
Journal of Physical Organic Chemistry

Page 20 of 23

1
2
3
4
5
6
7
8
9
9
10
11
12
13
14
15
16
17
18
19
20
21
22
23
24
25
26
26
27
28
29
30
31
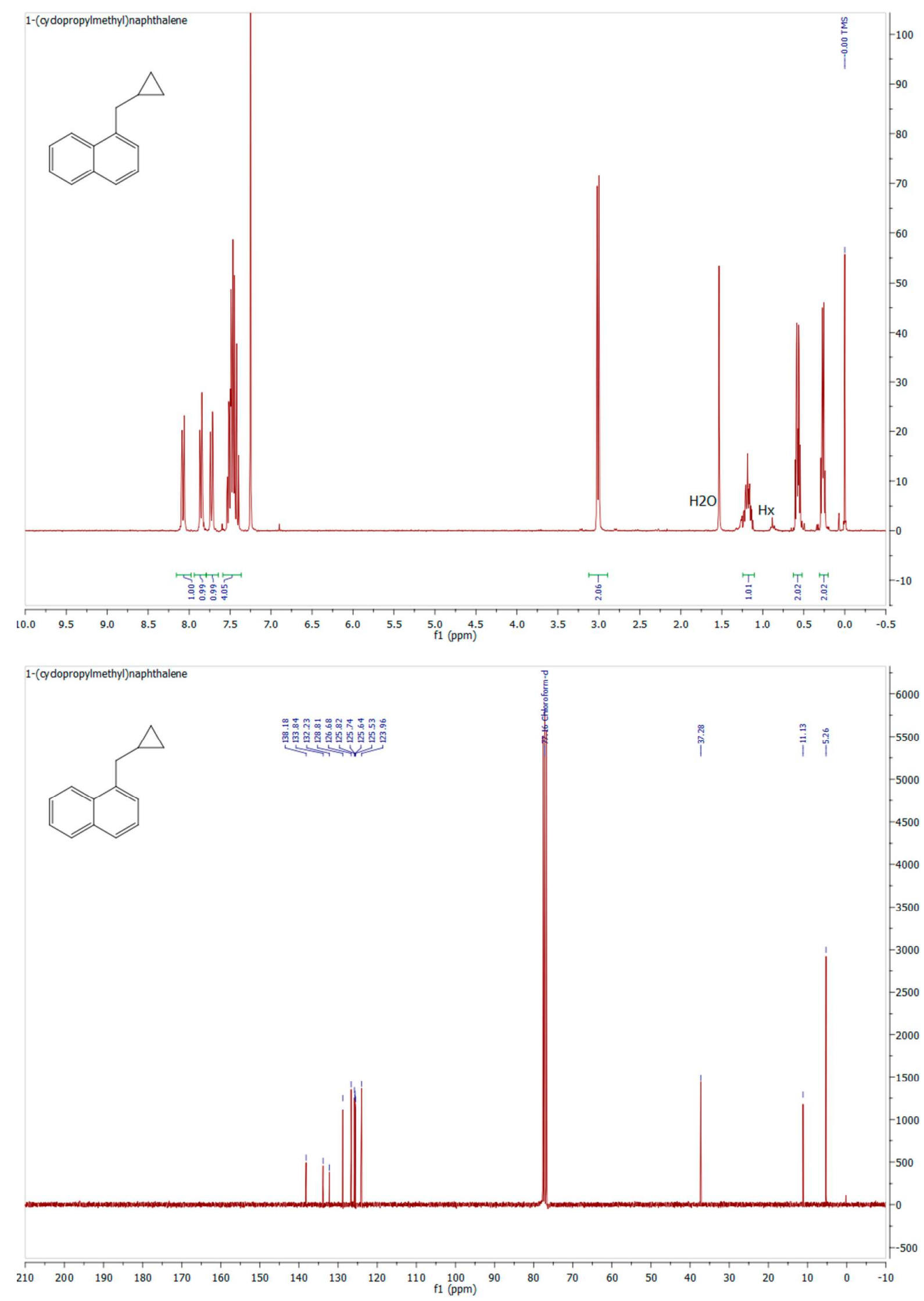

http://mc.manuscriptcentral.com/poc

Sq 
Page 21 of 23

Journal of Physical Organic Chemistry

1
2
3
4
5
6
7
8
8
9
10
11
12
13
14
15
16
17
18
19
20
21
22
23
24
24
25
26
27
2
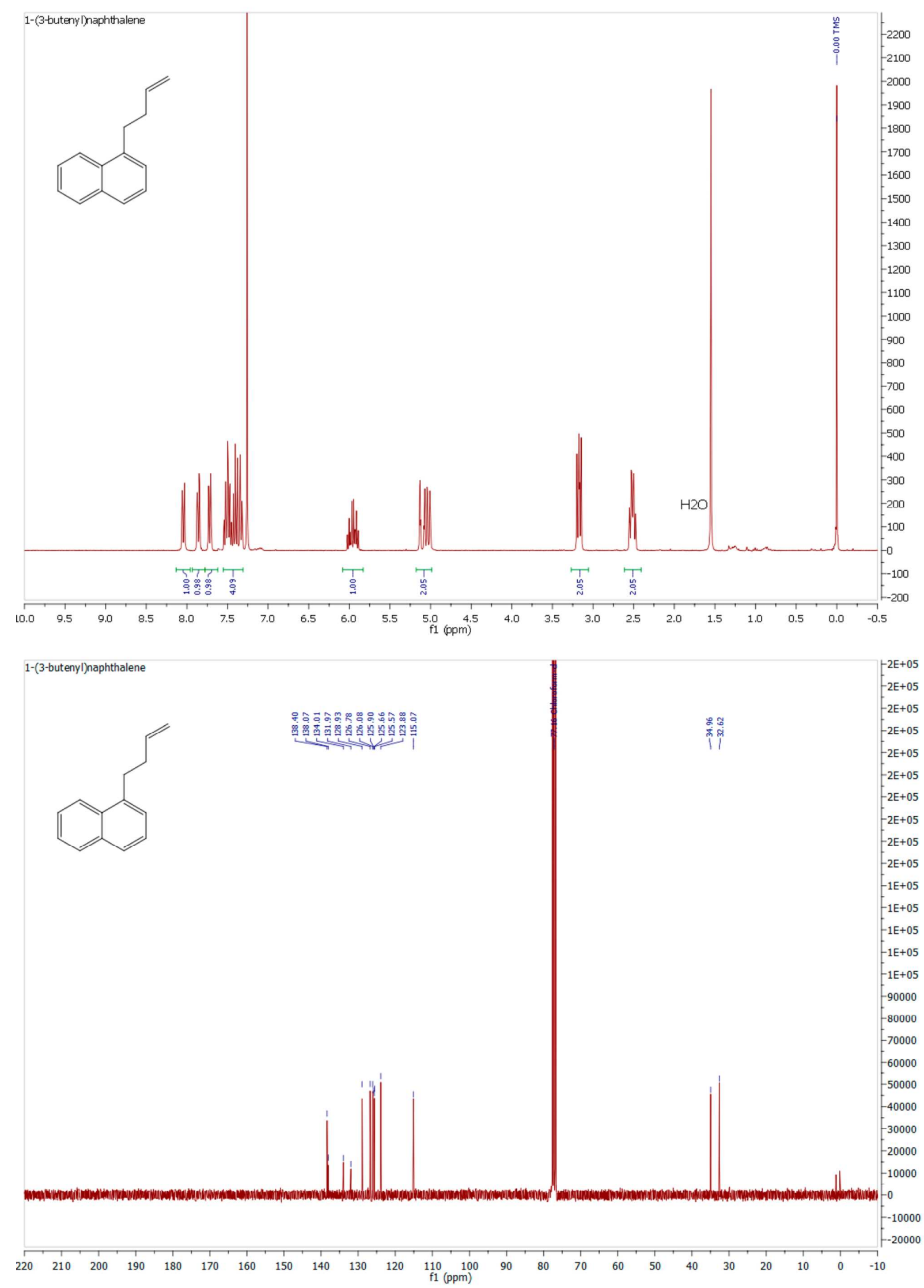

http://mc.manuscriptcentral.com/poc

$\mathrm{S} 10$ 

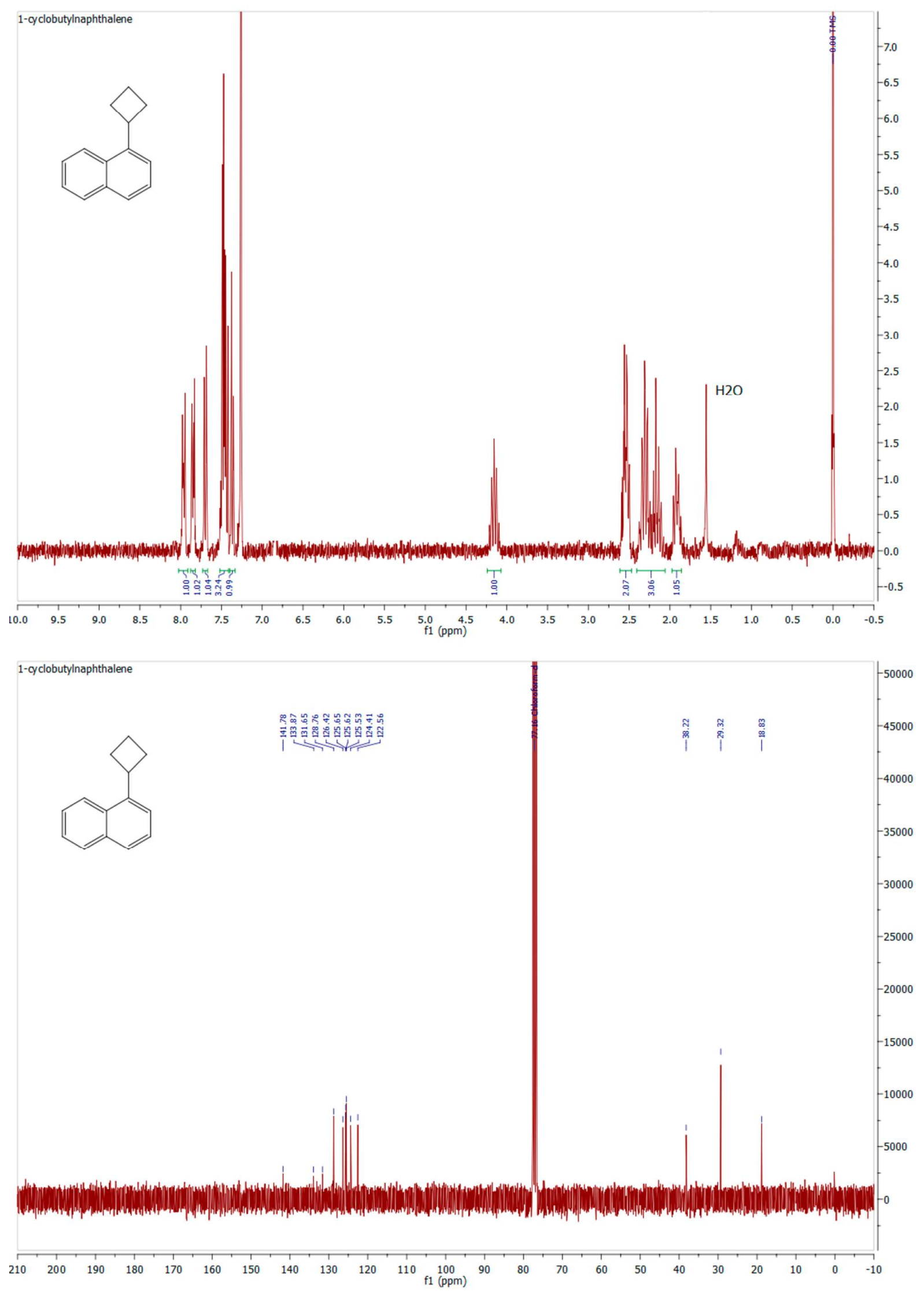

http://mc.manuscriptcentral.com/poc 
Table of contents

Inmaculada Blasco, Henoc Pérez and Albert Guijarro*

On the Reactivity of Naphthalene and Biphenyl Dianions: Tying up Loose Ends concerning an $S_{\mathrm{N}}$ 2-ET Dichotomy in Alkylation Reactions

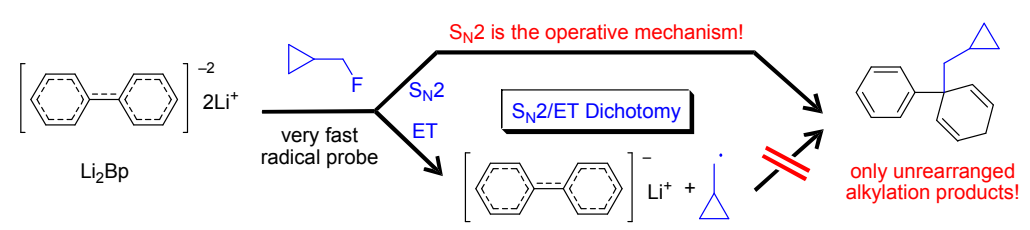

\section{Short Abstract:}

$S_{\mathrm{N}} 2$ or ET? The strength of the dianions of naphthalene and biphenyl as electron transfer (ET) reagents is comparable to the alkali metals, but contrary to other alkylating reagents, an $\mathrm{S}_{\mathrm{N}} 2$ reactivity is displayed when the substrate is an alkyl fluoride. This has been kinetically evidenced by means of a very fast radical probe (cyclopropylmethyl fluoride) which affords unrearranged alkylation products that do not originate from radical coupling but through a concerted $\left(\mathrm{S}_{\mathrm{N}} 2\right)$ pathway. 